\title{
Re-thinking the competition law/labour law interaction: promoting a fairer labour market
}

\author{
Ioannis Lianos, Nicola Countouris, and Valerio De Stefano
}

\section{Introduction}

In the Age of "secular stagnation"" and intense financialisation, when return to capital exceeds economic growth, and rentiers or senior executives, which form the bulk of the richest $1 \%$ of the population, see their share of total wealth increase, while that of the lower percentiles of the population, as well as those of the middle class stagnate or fall, questions of economic inequality become centre-stage. ${ }^{2}$ There is growing empirical evidence of increasing markups in the global economy, as a result of market power ${ }^{3}$, or because of higher concentration following an intense merger activity ${ }^{4}$. This "winner-take-most" competition game, where "superstar firms" command growing market shares and become highly profitable, has been linked to a larger decline in labour's share ${ }^{5}$.

At the same time we have witnessed important changes in the traditional model of the employment relationship that has accompanied the development of industrial capitalism, with the emergence of a 'New Economy Business Model', in particular in the high tech industry, that does not rely on career employment within the same company, but offers less employment security, emphasising interfirm mobility of labour, with the aim to maximise shareholder value $^{6}$. The dismantling of life-long and secure employment built on mutual loyalty and commitment of employers and employees, which was the hallmark of industrial capitalism, in favour of short-term and insecure employment of a mobile workforce that is always on lookout for new opportunities is a well-documented and well-understood story of labour in the latter part of the $20^{\text {th }}$ Century. ${ }^{7}$ A study conducted in the US, for instance, surveyed temporary help agency workers, on-call workers, contract workers, independent contractors, and freelancers, and found that their share in the entire worker-force rose from $10.7 \%$ in 2005 to $15.8 \%$ in 2015

\footnotetext{
${ }^{1}$ L. Summers, 'The Age of Secular Stagnation: What It Is and What to Do About It', Foreign Affairs (February 17, 2016) (noting the imbalance between excessive savings and investment, pulling down interest rates, savings tending to flow into existing assets, thus causing asset price inflation and rising economic inequality).

${ }^{2}$ T. Piketty, Capital in the Twenty-first Century (Harvard University Press, 2014); A. B. Atkinson, Inequality What can be done? (Harvard University Press, 2015).

${ }^{3}$ See generally Jan De Loecker \& Jan Eeckhout, The Rise of Market Power and the Macroeconomic Implications (Nat'l Bureau of Econ. Research, Working Paper No. 23687, 2017), http://www.nber.org/papers/w23687 [https://perma.cc/ED9S-8HET];

${ }^{4}$ See, J. Kwoka, Mergers, Merger Control, and Remedies (MIT press, 2014); J. Kwoka, 'Does Merger Control Work? A Retrospective on U.S. Enforcement Actions and Merger Outcomes', (2013) 78(3) Antitrust Law Journal 619.

${ }^{5}$ D. Autor, D. Dorn, L. Lawrence, F. Katz, C. Patterson \& J. Van Reenen, 'Concentrating on the Fall of the Labor Share', (2017) 107(5) American Economic Review 180.

${ }^{6}$ W. Lazonick, The New Economy Business Model and the Crisis of U.S. Capitalism (2009) 4(2) Capitalism and Society: 1.

${ }^{7}$ L. Boltanski, and E. Chiapello. The new spirit of capitalism (Verso. 2005); see also H. Ekbia, Digital Inclusion and Social Exclusion: The Political Economy of Value in a Networked World (2016) 32(2) The Information Society, 165-175.
} 
- a $50 \%$ increase in 10 years. ${ }^{8}$ By comparison, there was hardly any change in this regard between 1995 and 2005. More telling, 95\% of the net employment growth in the US economy (2005-2015) occurred in alternative work arrangements, while for standard employment arrangements the growth amounted to only $0.4 \%$. There are predictions that the majority of U.S. workers will be freelancing by 2027, thus leading to a very different structure of the labour market ${ }^{9}$. Although $44 \%$ of freelancers gained more than US£50000 gross income per year in $2018^{10}$, more than half of them work in more than two jobs, with five percent reporting having simultaneously four jobs or projects in order to be able to gain this income ${ }^{11}$.

The situation is also rapidly evolving in Europe. There were more than 1 million freelancers in the UK in 2017, the most populous occupation for being in the artistic, literary and media sectors ${ }^{12}$. These reported average earnings of approximately $£ 29000$, the medium annual earnings for full-time workers being during the same period $£ 28760$.

Of particular interest is the development of alternative work arrangements which are facilitated by digital platforms, which create new digital marketplaces to supply labour for temporary use ('labour value platforms') ${ }^{13}$. Schmidt provides a comprehensive taxonomy of these work arrangements, identifying two major categories each with three sub-categories, (i) Web-based Cloud work (which comprises freelance marketplaces, microtasking crowd work, and contest-based creative crowd work), and (ii) location based 'Gig' work (accommodation, transportation and delivery services, and household and personal services) ${ }^{14}$. This work may sometimes be categorised under the wide umbrella of Non-Standard and contingent work (selfemployed own account workers not hiring other individuals, temporary or fixed term contracts, and part-time work), although the way the work is organized, and the lack of alternatives in view of the dominance of these platforms, may be compared to the relation between employer and employee in traditional and long-term forms of employment ${ }^{15}$.

An increasing number of people provide services through online platforms such as Uber, Grubhub, Upwok, Handy, Deliveroo or TaskRabbit. The rise of these kinds of 'gig work' is becoming a global trend. It has been reported that of the 150.000 new jobs created in Denmark 2012-2017, 44\% were part-time jobs with 20 working hours per week or less, despite

\footnotetext{
${ }^{8}$ Katz, L. F., and Krueger, A. B. 2016. "The rise and nature of alternative work arrangements in the United States, 1995-2015."

${ }^{9}$ See, E. Pofeldt, Are We Ready For A Workforce That is 50\% Freelance?, Forbes (October 17, 2017), available at $\quad$ https://www.forbes.com/sites/elainepofeldt/2017/10/17/are-we-ready-for-a-workforce-that-is-50freelance/\#76afee263f82.

${ }^{10} \mathrm{See}$, https://www.statista.com/statistics/915926/gig-economy-workers-annual-income-before-taxes-us/ .

11 See, https://www.statista.com/statistics/915809/gig-economy-number-jobs-currently-held-gig-economyworkers/.

${ }^{12}$ See, https://www.statista.com/statistics/711419/united-kingdom-freelancing-professionals-type-of-work/ .

${ }^{13}$ V. De Stefano \& A. Aloisi, European legal framework for "digital labour platforms", (European Commission, 2018), available

http://publications.jrc.ec.europa.eu/repository/bitstream/JRC112243/jrc112243_legal_framework_digital_labour platforms_final.pdf.

${ }^{14}$ F. Schmidt, Digital Labour Markets in the Platform Economy: Mapping the Political Challenges of Crowd Work and Gig Work, (Friedrich Ebert Stiftung, 2017), available at https://library.fes.de/pdf-files/wiso/13164.pdf

${ }^{15}$ C. Codagnone, F. Abadie \& F. Biagi, The Future of Work in the 'Sharing Economy': Market Efficiency and Equitable Opportunities or Unfair Precarisation?, (Office of the European Union Institute for Prospective Technological Studies JRC Science for Policy Report, 2016).
} 
its strong unions and social contract between employers and employees. ${ }^{16}$ Other studies report similar trends. For instance, a study by JPMorgan-Chase (Farrell et al. 2016) found that $0.9 \%$ of adults in the USA participate in the online platform economy $-0.5 \%$ on labour platforms of the gig-economy (e.g. Uber, Taskrabbit) and $0.4 \%$ on capital platforms, leasing or selling their assets (e.g. Airbnb, eBay). Importantly, these numbers are the result of remarkable growth, which reached the $400 \%$ mark in late 2013 and most of 2014 before it slowed down to $102 \%$ in mid-2016. However, such growth is counteracted by high turnover rates; around one in six participants is new at any given month, while ca. $50 \%$ of participants exit within 12 months.

These important evolutions raise interesting questions as to the respective scope of labour law and competition law and their respective roles in engaging with, and regulating, these new emerging labour market dynamics. Traditionally, competition law focused on safeguarding competition on product markets, labour markets being, with a few exceptions, beyond its remit. This is partly due to the fact that competition law is traditionally perceived as regulating transactions taking place in the context of the market form of organisation, leaving hierarchies, that is relations taking place inside the firm, outside of its scope ${ }^{17}$. In contrast, labour law has traditionally focused on the regulation of the standard employment relationship embedded in the typical contract of subordinate employment, although in recent decades its focus has partly expanded to include some emerging forms of so-called atypical work relations, such as part-time, fixed-term, and temporary work. ${ }^{18}$ In the view of the present authors, this traditional allocation of tasks between employment law and competition law may not be fit for purpose in the era of the New Economy Business Model and the multiplication of alternative forms of labour.

This paper aims to suggest a different, complementary rather than antagonistic, relation between competition law and labour law. We initially explore the legal construction of the antagonistic relation between labour law and competition law, which is based on the conceptualization of the two areas of law as separate and isolated legal fields. We explain that such conceptualisation is conceptually problematic as it leads to the risk of fundamental conflicts between the two disciplines and some uncertainty as to their respective scope, with the result that the level of protection for labour may suffer. This calls, in our view, for breaking the dichotomy and for ensuring a continuum of protection for various forms of labour, under both labour law and competition law. This is examined in the third Section of this study, where we put forward concrete suggestions as to the strategies to be followed in order to achieve this goal. The last Section concludes.

\footnotetext{
${ }^{16}$ Damm, E. A. 2018. "Stor stigning i stillinger på mindre end 20 timer om ugen," The Economic Council of the Labour Movement, Copenhagen, DK.2018; See Marton, A. Ekbia, H.R. and Gruss, L-D. New Division of Labour: Of Humans, Machines and Platforms. The 34th EGOS Colloquium. 2018.

17 On the distinction between markets, hierarchies and the role of law, see, O Williamson, The Economic Institutions of Capitalism - Firms, Markets, Relational Contracting. (New York: Free Press, 1985); O Williamson, The Mechanisms of Governance (OUP, 1996).

${ }^{18}$ ILO, Non-Standard Employment Around the World - Understanding Challenges, Shaping Prospects (ILO, 2016); G. Davidov and B. Langille (eds.), The Idea of Labour Law (OUP, 2011); G. Casale (ed.), The Employment Relationship - A Comparative Overview (Hart, ILO, 2011).
} 


\section{The legal construction of an antagonistic relation: the separate and isolated fields approach}

\section{A. Labour Law and the Distinction between Employees and Self-employed}

Labour law typically draws a distinction between subordinate 'employees' and the autonomous 'self-employed'. Some Member States (E.g. Spain, the UK, Italy, Germany, Austria...) contemplate intermediate categories of semi-dependent workers, that are usually understood as sub-categories of self-employment. ${ }^{19}$ Other Member States (France, Belgium, Sweden,...) do not contemplate intermediate categories, but their notions of 'worker' are very broad and include several personal work providers that in other systems would be seen as 'self-employed' persons.

Self-employment is typically not defined in any great detail by domestic labour law systems, or by EU law for that matter. Usually the concept operates as a residual category: if a person does not meet the often very detailed criteria and indicators used to identify who is an 'employee' or 'worker', labour law will assume, almost by default, that that person is selfemployed. Because of this approach, the concept of self-employment encompasses a very broad and heterogeneous range of service providers. It can include both self-employed persons that exclusively sell their personal labour (often to a single client or to a limited number of clients or customers), but also self-employed persons that offer highly capitalised services, including by recruiting staff in order to offer such services. ${ }^{20}$

The scope of application of EU labour law is defined by reference to the concepts of 'worker' and 'self-employed'. EU labour law does not contemplate any 'intermediate' class of workers. The EU labour law concept of 'worker' derives from the CJEU case law in the area of Free Movement of Workers (FMW) ${ }^{21}$.

'The defining feature of an employment relationship resides in the fact that for a certain period of time a person performs for and under the direction of another person services in return for which he receives remuneration, 22 .

The circumstance that the EU labour law concept of 'worker' derives from the EU free movement concept of worker is quite relevant. The Court's insistence on the concept of subordination and control in the FMW context is immaterial to the free movement rights enjoyed by EU citizens, since even autonomous self-employed workers can enjoy these

\footnotetext{
${ }^{19}$ A. Perulli, Economically dependent / quasi-subordinate (parasubordinate) employment: legal, social and economic aspects (Brussels, 2003); Eurofound, Exploring self-employment in the European Union (Publications Office of the European Union, 2017); J. Fudge, 'A Canadian perspective on the scope of employment standards, labor rights, and social protection: The good, the bad, and the ugly' (2010) Comparative Labour Law and Policy Journal, Vol. 31, No. 2, pp. 253-266. See also the various chapters in the present special issue.

${ }^{20}$ Cf. N. Countouris and V. De Stefano, New Trade Union Strategies for New Forms of Employment (ETUC, 2019).

${ }^{21}$ See cases such as C-256/01, Allonby and C-313/16, Fennol. M. Risak and T. Dullinger, 'The concept of 'worker' in EU law: status quo and potential for change' (ETUI, 2018); N. Kountouris, 'The Concept of 'Worker' in European Labour Law: Fragmentation, Autonomy and Scope' (2018) ILJ, 192-225.

${ }^{22}$ Case C-518/15, Matzak, para. 28.
} 
freedoms under the rubrics of freedom of establishment and freedom of services. But by carrying the FMW 'worker' concept in the EU labour law context, control and subordination can have very clear exclusionary consequences since, as a general rule, self-employed workers do not receive many labour law rights.

The development of platform work raises interesting questions, not only in the EU but also in other jurisdictions, as to the criteria that would enable courts and public authorities to distinguish between workers and self-employed and have raised questions as to the preeminence of the employment test as to whether the alleged employer has the right to control the manner and means of accomplishing the result desired. Of particular interest is the recent judgment of the Supreme Court of California in the Dynamex litigation ${ }^{23}$. Emphasizing the statutory purpose as the touchstone for deciding whether a particular category of workers should be considered employees rather than independent contractors, the California Supreme Court distinguished between three standards in determining the boundary between 'workers' and 'self-employed' for the purposes of the 'wage orders' under the state law in California which provide minimum wage, maximum hour, and working condition requirements for specific industries.

First, there is the common law standard of the hirer's right to control the details of the work, which as we described above also inspires the approach followed in EU law, which is often supplemented by a number of secondary factors that assist the decision-maker in the implementation of the test ${ }^{24}$. Second, the US courts have developed the "the "economic reality" (or "economic realities") standard', which treats as employees 'those workers who, as a matter of economic reality, are economically dependent upon the hiring business, rather than realistically being in business for themselves' ${ }^{25}$. Again, the courts make a multi-factor determination focusing, inter alia, on 'the workers' opportunity for profit or loss and their investment in the business', 'the degree of skill and independent initiative required to perform the work', 'the permanence or duration of the working relationship', and 'the extent to which the work is an integral part of the employer's business ${ }^{26}$. As the second test requires a significant effort of analysis, some US courts adopted the simpler and clearer 'ABC standard'27. This standard places the burden on the hirer to establish that the worker is an independent contractor by assuming that the worker is an employee, unless the hiring entity cumulatively satisfies the following three factors: (A) 'that the worker is free from control and direction over performance of the work, both under the contract and in fact'; (B) 'that the work provided is outside the usual course of the business for which the work is performed'; and (C) 'that the worker is customarily engaged in an independently established trade, occupation or business ${ }^{28}$.

\footnotetext{
${ }^{23}$ Dynamex Operations West v. Superior Court of Los Angeles County, 4 Cal.5th 903 (2018).

${ }^{24}$ These are, in addition to the control of the details of work the following five, thus constituting a 'six-factor test': '(1) the alleged employee's opportunity for profit or loss depending on his managerial skill; (2) the alleged employee's investment in equipment or materials required for his task, or his employment of helpers; (3) whether the service rendered requires a special skill; (4) the degree of permanence of the working relationship; and (5) whether the service rendered is an integral part of the alleged employer's business'. The Court cites $S$. G. Borello \& Sons, Inc. v. Department of Industrial Relations (1989) 48 Cal.3d 341, 354-355.

${ }^{25}$ Dynamex Operations West v. Superior Court of Los Angeles County, 4 Cal.5th 903 (2018), fn 20 (emphasis added).

${ }^{26} \mathrm{Ibid}$.

${ }^{27}$ Ibid.

${ }^{28} \mathrm{Ibid}$.
} 
According to the California Supreme Court in Dynamex, the ABC test provides a less wideranging and flexible test than the 'economic realities' standard. The Court suggests to start by examining factors $\mathrm{B}$ and $\mathrm{C}$ first, before moving to the more evidentially demanding factor $\mathrm{A}$, if need be. For instance, if a worker has not independently decided to engage in an independently established business but instead was simply designated an independent contractor by the unilateral action of the hiring entity, then there is a high risk of misclassification and the factor $\mathrm{C}$ may not be satisfied. Furthermore, concerning factor $\mathrm{B}$, the courts should examine if the role in question is comparable to that of employees in the specific course of business of the hiring entity. Factor A is similar to the common law standard previously examined. The judgment of the California Supreme Court has important implications as to the qualification of the activity of platform workers, and therefore the personal scope of labour law protection. It may also provide inspiration as to the possible use of similar factors under EU labour law. By referring to the existence of economic dependence as a relevant factor for the qualification of the distinction between 'employees' and 'selfemployed', it hints to the possibility that a common criteria, based on economic realities, may apply for both EU labour law and EU competition law.

However, there are exceptions to the general rule that self-employed do not benefit from the labour law protection, thus hinting to the emergence of hybrid regimes. For instance, most EU Member states, and arguably EU Law, accept that even the self-employed ought to be protected against discrimination. ${ }^{29}$ Several Member states also accept that freedom of association and collective bargaining are fundamental rights - often enshrined at a constitutional level - to be enjoyed by all workers, including self-employed workers. ${ }^{30}$ In other countries, such as France, express legal presumptions extend the bulk of labour rights to various types of self-employed persons, such as freelance journalists, performing artists, models, etc. When Member States contemplate the existence of intermediate categories of semi-dependent or economically dependent (self-employed) workers, their rights can vary considerably, but by and large these intermediate categories receive more labour rights than the self-employed and fewer than standard workers. ${ }^{31}$

None of these nuances is reflected in the EU labour law distinction between 'workers' and 'self-employed'. The only exception is arguably the right not to be discriminated against, that also applies to 'conditions for access to employment, to self-employment and to occupation' (e.g. Article 3 (1)(a) of Dir. 2000/43).

When it comes to collective bargaining, labour law systems provide strong justifications for allowing workers to combine with each other and agree with employers basic terms and conditions of employment, including pay and working time. These justifications typically revert around the inability of workers to extract a fair price for their labour on an individual bargaining basis: by the very fact of being labourers, and in consideration of their need to

\footnotetext{
${ }^{29}$ N. Countouris and M. Freedland, The Personal Scope of EU Sex Equality Directives (European Network of Legal Experts in the Field of Gender Equality, 2013).

${ }^{30}$ V. De Stefano, "Non-Standard Work and Limits on Freedom of Association: A Human Rights-Based Approach" 46 [2017] Industrial Law Journal 185.

31 A. Perulli, 'Subordinate, Autonomous an Economically Dependent Work: A Comparative Analysis of Selected European Countries', in G. Casale (Ed.), The Employment Relationship. A Comparative Overview (Hart, ILO, 2011), p. 159.
} 
constantly sell their labour in order to make a living, workers are ultimately not in a position truly to negotiate terms of employment, that are therefore typically imposed on them. By protecting the right to collective bargaining, labour law seeks to redress this imbalance of power and achieve fair outcomes for workers.

Since labour law is primarily concerned with fairness, it sometimes allows some selfemployed persons to either participate in collective bargaining processes or to benefit from their outcomes. This is typically justified on the same fairness and anti-subordination basis as discussed above: by virtue of not being able to rely on any substantial capital assets, and by selling labour or labour intensive services that could easily act as cheap substitutes for the personal labour offered by standard workers, their inclusion in collective bargaining outcomes ensure both fairness and a level playing field. This is increasingly so as human resource management practices and technological changes are increasingly bringing to the fore new forms of work that are designed to look like genuinely autonomous employment relationship, while allowing employers and principals to avail themselves of personal work and labour services but without having a workforce, at least in the traditional sense.

International and European Labour Law are also adamant about freedom of association and the right to bargain collectively also applying to the self-employed. The ILO Committee on Freedom of Association considers that "by virtue of the principles of freedom of association, all workers - with the sole exception of members of the armed forces and the police - should have the right to establish and join organizations of their own choosing", therefore, the criterion for "determining the persons covered by that right" is "not based on the existence of an employment relationship, which is often non-existent, for example in the case of agricultural workers, self-employed workers in general or those who practise liberal professions, who should nevertheless enjoy the right to organize." 32 According to the ILO Committee , the right to collective bargaining extends to self-employed workers, and ILO member States are expected "to take the necessary measures to: (i) ensure that "self-employed" workers, such as heavy goods vehicle drivers, fully enjoy freedom of association rights, in particular the right to join the organizations of their own choosing; (ii) to hold consultations to this end with all the parties involved with the aim of finding a mutually acceptable solution so as to ensure that workers who are self-employed could fully enjoy trade union rights under Conventions Nos 87 and 98 for the purpose of furthering and defending their interest, including by the means of collective bargaining; and (iii) in consultation with the social partners concerned, to identify the particularities of self-employed workers that have a bearing on collective bargaining so as to develop specific collective bargaining mechanisms relevant to self-employed workers, if appropriate'. ${ }^{33}$ The Committee of Experts on the Applications of Conventions and Recommendations (CEACR) also repeatedly argued in the same direction. ${ }^{34}$

Instruments of the Council of Europe also recognise freedom of association and collective bargaining for the self-employed. The European Court of Human Rights, for

\footnotetext{
${ }^{32}$ See ILO. 2018. Freedom of Association Compilation of decisions of the Committee on Freedom of Association. Sixth edition (2018), Geneva, ILO, para. 387.

${ }^{33}$ Ibid.

${ }^{34}$ For instance, see, ILO. 2012. Giving globalization a human face General Survey on the fundamental Conventions concerning rights at work in light of the ILO Declaration on Social Justice for a Fair Globalization, 2008. ILO, Geneva, para. 53
} 
instance, has extended the protection of freedom of association under article 11 of the European Convention of Human Rights to self-employed persons. ${ }^{35}$ Very recently, the European Committee of Social Rights also clearly stated that self-employed workers are protected under Article $6 \$ 2$ of the European Social Charter, which grants the right to bargain collectively, and observed that "an outright ban on collective bargaining of all self-employed workers would be excessive as it would run counter to the object and purpose of this provision". ${ }^{36}$

\section{B. Competition Law and the Distinction between Undertakings and Workers}

Normally, competition law is seen as applying to 'undertakings', and most competition law systems exonerate themselves from interfering within the boundaries of the undertaking, in particular with the way workers and management interact. In most legal systems, including the EU law one, the concept of 'undertaking is widely interpreted as 'an entity engaged in economic activity' ${ }^{37}$. It includes individual persons offering goods or services on a market where they bear financial risk attached to performance of those services ${ }^{38}$. However, an employee cannot be an undertaking as it does not exercise an autonomous economic activity, in the sense of offering goods or services on a market and bearing the financial risk attached to the performance of such activity. So when workers combine with each other and conclude collective agreements with employers to fix a rate, or a price, for the sale of their labour, competition law systems typically see these practices as something quite distinct from the price fixing practices that undertakings may be engaging in. ${ }^{39}$

In essence, collective agreements concluded by unions on behalf of their workers typically benefit from an exclusion from the scope of EU competition law. Employees/workers cannot be undertakings under EU competition law, as they do not exercise an autonomous economic activity, in the sense of offering goods or services on a market and bearing the financial risk attached to the performance of such activity. By the same token, a labour agreement between an employer and an employee will not fall under the scope of Article 101(1) TFEU, as it will not be an agreement between 'undertakings'. ${ }^{40}$

In Jean Claude Becu the CJEU examined a collective labour agreement relating to dock work at the Port of Ghent, made mandatory by Royal Decree, which allowed only duly recognized dockers to perform dock work, and also made the outcome of collective bargaining between employers' and employees' representatives negotiations binding erga omnes. The preliminary question sent to the CJEU by the national court involved the possible application

\footnotetext{
${ }^{35}$ Vörđur Ólafsson v. Iceland, Application no. 20161/06.

36 European Committee of Social Rights, Irish Congress of Trade Unions (ICTU) v. Ireland Complaint No.123/2016, adopted 12 September 2018, para. 40.

${ }^{37}$ Case C-41/90, Höfner and Elser [1991] ECR I-1979.

${ }^{38}$ Case C-35/96, Commission v Italy (customs agents) [1998] ECR I-3851.

${ }^{39}$ See the Opinion of AG Jacobs in Case C-67/96, Albany International BV (ECLI:EU:C:1999:28), esp. paras 80112.

${ }^{40}$ See Joined Cases 40-8/73 etc, Coöperatieve Vereniging 'Suiker Unie' UA and others v Commission [1975] ECR 1663, para 539 (referring to the situation of an agent forming integral part of the undertaking of a principal). For a discussion, see P Nihoul, 'Do Workers Constitute Undertakings for the Purpose of the Competition Rules?' (2000) 25(4) European L Rev 408; C Townley, "The Concept of "Undertaking": The Boundaries of the Corporation-A Discussion of Agency, Employees and Subdidiaries' in G Amato and C-D Ehlermann (eds) EC Competition Law: A Critical Assessment (Hart, 2007), 3
} 
of both Articles 102 and 106(1) TFEU to the Belgian Royal Decree. The CJEU assessed if these dock workers could be considered an 'undertaking'. The CJEU held that

'[...] the employment relationship which recognised dockers have with the undertakings for which they perform dock work is characterised by the fact that they perform the work in question for and under the direction of each of those undertakings, so they must be regarded as 'workers' within the meaning of [Article 45 TFEU], as interpreted in the case law [. . .].

Since they are, for the duration of that relationship, incorporated into the undertakings concerned and thus form an economic unit with each of them, dockers do not therefore in themselves constitute undertakings. ${ }^{41}$

It is worthwhile noticing that in Becu the CJEU effectively aligned the concept of 'employee' with that of the 'worker' under Article 45 TFEU. ${ }^{42}$ From the Court's reasoning it also followed that workers could not be considered as an undertaking if they were acting collectively as associations of workers. It is worth noting that often their contracts of employment tied them to a particular ship owner on a fixed-term basis, and 'as a rule for short periods, and for the purposes of performing clearly defined tasks' (para 25 of Becu). The work relations of dockers are notoriously short and can often last even less than a working day and only amount to the performance of one task, such as loading or unloading a particular cargo from a particular ship. Other patterns can of course be different, but none of this was material to the findings of the Court as its analysis focused on the nature of the employment

\footnotetext{
${ }^{41}$ Case C-22/98, Criminal proceedings against Jean Claude Becu, Annie Verweire, Smeg NV and Adia Interim $N V$ [1999] ECR I-5665. It is noteworthy that the situation of employees is dealt differently in the EU than in the US. In US law, all 'persons' are subject to the Sherman Act, unless they benefit from an exemption. Labour benefits from a statutory and a non-statutory exemption. The statutory labour exemption (Clayton Antitrust Act, 15 USC $\S \S 12-27$; Norris-La Guardia Act, 29 USC $\S \S 101-15)$ enables workers to organize to eliminate competition among themselves, and to pursue their legitimate labour interests, so long as they act in their selfinterest and do not combine with a non-labour group. Yet, the statutory labour exemption did not immunize the collective bargaining process or collective bargaining agreements themselves from potential antitrust liability, but covered only labour's organizations unilateral actions. The US courts thus developed the non-statutory basis of the labour exemption in order to remove from antitrust scrutiny restraints in trade that are the product of a collective bargaining agreement between labour and management (see Local Union No 189, Amalgamated Meat Cutters \& Butcher Workmen of N Am v Jewel Tea Co Inc, 381 US 676 (1965)). These more typically apply to agreements between employees or their unions and employers when the agreements are intimately related to a mandatory subject of bargaining, and do not have 'a potential for restraining competition in the business market in ways that would not follow naturally from elimination of competition over wages and working conditions': Connell Constr Co v Plumbers \& Steamfitters Local Union No 100, 421 US 616, 635 (1975). According to the US Supreme Court (ibid, 622), '[t] he non statutory exemption has its source in the strong labor policy favoring the association of employees to eliminate competition over wages and working conditions. Union success in organizing workers and standardizing wages ultimately will affect price competition among employers, but the goals of federal labour law never could be achieved if this effect on business competition were held a violation of the antitrust laws. The Court therefore has acknowledged that labour policy requires tolerance for the lessening of business competition based on differences in wages and working conditions'. Courts have even extended this immunity beyond the expiration of a collective bargaining agreement: see Brown $v$ NFL, 518 US 231 (1996).The non-statutory labour exemption has been frequently applied in the field of professional sports, for instance exempting a labour agreement between the US National Football League (NFL) or the National Basketball Association (NBA) and a national union of student-athletes.

${ }^{42}$ See also AG N Wahl Opinion in Case C-413/13 FNV Kunsten Informatie en Media v Staat der Nederlanden [2014] ECLI:EU:C:2014:2215, n 4 (using the terms 'employee' and 'worker' interchangeably).
} 
relationships (and it goes without saying that it may have reached a different characterization in a different factual context). ${ }^{43}$

It is fair to say that, since Весu, the possible application of Article 101 TFEU to collective agreements concluded between trade unions and associations of employers has led to the development of a fully fledged exception to the application of EU competition law, for reasons of social policy. EU competition law, as developed by the Court, now provides immunity from competition law to collective labour agreements concluded between associations of workers (labour unions) and employers, when two cumulative conditions are met: (i) they are entered into in the framework of collective bargaining between employers and employees and (ii) they contribute directly to improving the employment and working conditions of workers. This case law does not, however, relate to the concept of 'undertaking' as such, but mostly to that of the restriction of competition and is known as the Albany exception.

In Albany ${ }^{44}$ the Court clearly took the view that it was 'beyond question that certain restrictions of competition are inherent in collective agreements between organisations representing employers and workers'. However, it was also willing to concede that 'the social policy objectives pursued by such agreements would be seriously undermined if management and labour were subject to [EU competition rules] when seeking jointly to adopt measures to improve conditions of work and employment' (para 59). This concession was premised on various treaty-based textual justifications but also on the understanding that the 'nature and purpose' of the agreement was that of 'improving ... working conditions, namely ...remuneration' (para 63). The CJEU found that, first, the collective agreement at issue was concluded in the form of a collective agreement and was the outcome of collective negotiations between organizations representing employers and workers, and second, its purpose, the establishment of a supplementary pension scheme aiming to guarantee a certain level of pension for all workers in the sector 'contributed directly to improving one of their working conditions, namely their remuneration', ${ }^{45}$ consequently excluding this agreement from the scope of Article 101(1) TFEU.

Exercising a liberal professions has usually being found to constitute an economic activity falling under the scope of competition law if there is no relation of employment. ${ }^{46}$ But would the Albany exception apply to exclude from the scope of Article 101(1) TFEU collective agreements concluded between the members of liberal professions with regard to the fixing of minimum rates or other agreements restricting competition between them, to the extent that self-employed are considered to be undertakings? ${ }^{47}$ The CJEU has examined the categorization

\footnotetext{
${ }^{43}$ C Townley, 'The Concept of "Undertaking": The Boundaries of the Corporation-A Discussion of Agency, Employees and Subdidiaries' in G Amato and C-D Ehlermann (eds) EC Competition Law: A Critical Assessment (Hart, 2007), 5

${ }^{44}$ Case C-67/96, Albany International BV v Stichting Bedrijfspensioenfonds Textielindustrie [1999] ECR I-5751.

${ }^{45} \mathrm{Ibid}$, paras $62-63$.

46 See, for instance, self-employed accountants (Case C-1/12, Ordem dos Técnicos Oficiais de Contas, ECLI:EU:C:2013:127), pharmacists (Case T-23/09, CNOP \& CCG v Commission [2010] ECR II-5291), medical doctors (Joined Cases C-180-4/98, Pavel Pavlov and Others v Stichting Pensioenfonds Medische Specialisten [2000] ECR I-6451), and musicians (Case C-413/13, FNV Kunsten Informatie en Media, ECLI:EU:C:2014:2411). ${ }^{47}$ See Joined Cases C-180-4/98, Pavel Pavlov and Others v Stichting Pensioenfonds Medische Specialisten [2000] ECR I-6451; Belgian Architects Association (Case 2005/8/CE) Commission Decision [2005] OJ L 4/10.
} 
of an association acting on behalf of self-employed persons, and has also explored the extension of the Albany exception to collective agreements concluded by unions representing both employees and self-employed persons.

Under the current approach followed by the EU courts, an association acting on behalf of self-employed persons is to be regarded as an association of undertakings under Article 101(1) TFEU $^{48}$. It has become increasingly clear that a) when the self-employed seek to bargain collectively the terms and conditions of their services, or b) where collective agreements concluded by trade unions for subordinate workers also contain minimum labour costs provision that also apply to self-employed workers, then the exclusion from competition law will not apply to such self-employed workers as competition authorities or courts see them as 'undertakings'.

As for (a), in Pavlov, a collective agreement also setting up a pension fund, but concluded by an 'organisation ... made up solely of self-employed medical specialists' did not fall under the Albany exception and the organisation was seen as acting as an association of 'undertakings' and as such subject to competition law ${ }^{49}$. This was so because 'the Treaty did not contain any provisions 'encouraging the members of the liberal professions to conclude collective agreements with a view to improving their terms of employment and working conditions, ${ }^{50}$.

As for (b) in FNV Kunsten the Court held that 'in so far as an organisation representing workers carries out negotiations acting in the name, and on behalf, of those self-employed persons who are its members, it does not act as a trade union association and therefore as a social partner, but, in reality, acts as an association of undertakings ${ }^{\prime 51}$, and is therefore also exposed to the full application of EU Competition law rules. An exception to these rules, the Court said in FNV Kunsten, is only possible 'if the service providers, in the name and on behalf of whom the trade union negotiated, are in fact "false self-employed", that is to say, service providers in a situation comparable to that of employees, ${ }^{52}$.

\section{The Problem: A Conceptual and Normative Mismatch between the categories and Goals of Labour Law and EU Competition Law}

In our view, the different approaches taken by labour law and competition law can lead to fundamental conflicts between the interests and rights protected by the two disciplines.

Labour law clearly increasingly sees it necessary to include some self-employed workers within collective bargaining processes or within its outcomes. This is particularly so because, in the last two decades, a constantly growing number of economic relations in the

\footnotetext{
${ }^{48}$ Case C-309/99, JCJ Wouters, JW Savelbergh and Price Waterhouse Belastingadviseurs BV v Algemene Raad van de Nederlandse Orde van Advocaten, intervener: Raad van de Balies van de Europese Gemeenschap [2002] ECR I-1577. In Wouters, the CJEU examined the compatibility with Article 101 TFEU of a regulation adopted by the Netherlands Bar Association prohibiting lawyers practising in the Netherlands from entering into multidisciplinary partnerships with members of the professional category of accountants.

49 Case C-180/98, Pavel Pavlov and Others v Stichting Pensioenfonds Medische Specialisten, ECLI:EU:C:2000:428, para. 72.

${ }^{50}$ Ibid., para 69.

${ }^{51}$ Case C-413/13, FNV Kunsten Informatie en Media v Staat der Nederlanden, ECLI:EU:C:2014:2411, para. 28.

${ }^{52}$ Ibid., para. 31.
} 
labour market is increasingly being configured as relations between self-employed persons and their clients/customers, rather than as work relations between workers and employers. As put by the European Committee of Social Rights in its Complaint No. 123/2016, ICTU v Ireland decision:

'the world of work is changing rapidly and fundamentally with a proliferation of contractual arrangements, often with the express aim of avoiding contracts of employment under labour law, of shifting risk from the labour engager to the labour provider. This has resulted in an increasing number of workers falling outside the definition of a dependent employee, including low-paid workers or service providers who are de facto "dependent" on one or more labour engagers. These developments must be taken into account when determining the scope of Article $6 \S 2$ in respect of self-employed workers' (para 37).

So while labour law is increasingly accepting that many workers classified as selfemployed are mainly or solely providing personal work to 'labour engagers', competition law is reluctant to accept the view that persons that labour law classifies as self-employed ought to be granted any exceptions from its scope of application. Competition law relies of a different binary classification and distinction, that between 'workers' and 'undertakings'. If one is not a dependent worker then it will necessarily be an undertaking. The only exception that competition law contemplates is, as noted above, in respect of employees that have been misclassified as (false) self-employed. Allowing undertakings to combine with each other and fix their prices is rightly seen as clashing with the fundamental tenets of competition law, distorting markets, harming business, and harming consumers.

EU competition law, in its current state, constitutes an important barrier for the extension of collective labour rights to platform workers and free lancers, as well as any other category of self-employed, to the extent that self-employed are considered as 'undertakings'.

Article 101(1) TFEU prohibits collusive conduct between undertakings that are competitors in a definable market. Agreements between competitors regarding the price they will charge for a product or service are considered as serious infringements and restrictive of competition by their object, without the need to explore the existence of anticompetitive effects in a definable relevant market, but instead examining a number of factors, such as the content of the provisions of the agreement, concerted practice or decision of association of undertakings, its objectives and the economic and legal context of which it forms a part ${ }^{53}$. Article 101(3) creates exception to Article 101(1) if the agreement or decision contributes to economic progress and competition is not eliminated, but as we will subsequently explain, this possibility of justification is quite limited and could not provide the required legal certainty for the development of collective bargaining for various categories of self-employed.

\footnotetext{
${ }^{53}$ See, Joined Cases C-501/06 P, C-513/06 P, C-515/06 P and C519/06 P GlaxoSmithKline [2009] ECR I-9291, para. 58, Joined Cases 96/82 to 102/82, 104/82, 105/82, 108/82 and 110/82 IAZ International Belgium and Others [1983] ECR 3369, para. 25, Case C-209/07 Beef Industry Development Society (BIDS) [2008] ECR I-8637, para. 16; Case C-32/11 Allianz Hungária Biztosító Zrt and Others, ECLI:EU:C:2013:160, para. 36; Case C-67/13 P, Groupement des cartes bancaires (CB) v. Commission, ECLI:EU:C:2014:2204, para. 52.
} 
Article 102 TFEU prohibits an abuse of a dominant position by an undertaking(s), to the extent that a group of undertakings may be found in a collective dominant position. The constitution of an agreement or joint action between undertakings certainly satisfies the conditions of the case law for the existence of economic links or factors which give rise to a connection between the undertakings concerned that 'enable them to act together independently of their competitors, their customers and consumers" ${ }^{54}$. According to the jurisprudence of the EU courts, '[t]hree cumulative conditions must be met for a finding of collective dominance: first, each member of the dominant oligopoly must have the ability to know how the other members are behaving in order to monitor whether or not they are adopting the common policy; second, the situation of tacit coordination must be sustainable over time, that is to say, there must be an incentive not to depart from the common policy on the market; thirdly, the foreseeable reaction of current and future competitors, as well as of consumers, must not jeopardise the results expected from the common policy ${ }^{55}$. This opens the possibility for associations of self-employed which may be considered as undertakings to fall under the prohibition of Article 102 TFEU for a number of their activities, for instance setting a minimum wage or a minimum fee for their work or services, if these may be found to constitute an abuse of a dominant position (e.g. excessive pricing), even if this arrangement does not fall under Article 101 TFEU, for instance because of the Albany exception.

Articles 106(1) and 106(2) TFEU also subject to the discipline of Articles 101 and 102 TFEU public undertakings and undertakings to which Member States grant special or exclusive rights. One may refer to the collecting society model, put in place for the collective management of copyright rights by authors and other creatives, which benefitted from a de facto or statutory monopoly in each Member State and whose activities were regulated under domestic legislation and national regulatory measures that widely differed in their approach, at least until the implementation of the 2014 Collective Rights Management Directive ${ }^{56}$. Collecting societies were organised in some Member States more than in others, according to the principle of solidarity, as they required all right holders to pay the same fee for the administration of their rights and relied on cross-subsidisation of the less successful artist by the most successful ones, for instance through the organisation of hardship funds that represented for some collecting societies a substantial amount of transfers for social purposes ${ }^{57}$. The collecting society model has nevertheless been subject to strict competition law scrutiny and was gradually transformed with the increasing emphasis put, in particular since the Commission's recommendation 2005/737/EC in 2005, on promoting cross-border competition between collecting societies, thus progressively breaking the monopoly positions they

\footnotetext{
${ }^{54}$ Case C-395/96 P Compagnie Maritime Belge [2000] ECR I-1365, paras 41-42.

${ }^{55}$ Case T-193/02 Laurent Piau v. Commission [2005] ECR II-209 para 111.

${ }^{56}$ Directive 2014/26/EU of the European Parliament and of the Council of 26 February 2014 on collective management of copyright and related rights and multi-territorial licensing of rights in musical works for online use in the internal market, [2014] OJ L 84/72. The Directive sets out the standards that EU Collective Management Organisations (CMOs) which choose to engage in multi-territorial licensing of online musical rights must meet.

${ }^{57}$ See, the discussion in S. Schroff \& J. Street, The politics of the Digital Single Market: culture vs. competition vs. copyright, (2018) 21(10) Information, Communication \& Society 1305, 1317, detailing that in 2011, the German GEMA distributed 5.9\% of its distributable income for social purposes, including pensions, hardship funds and promotion, the French SACEM 7\% and the Spanish SGAE 9.6\%.
} 
benefitted from ${ }^{58}$. The agreements concluded by collecting societies have been since assessed under Article 101 TFEU, in recent years, for several dimensions of their activity ${ }^{59}$.

According to Article 106(2) TFEU, undertakings entrusted with the operation of services of general economic interest or having the character of a revenue-producing monopoly shall be subject to the rules contained in the Treaties, in particular to the rules on competition, in so far as the application of such rules does not obstruct the performance, in law or in fact, of the particular tasks assigned to them. However, the establishment of state granted monopolies has also been subject to intense competitive scrutiny.

Finally, Article 4(3) TEU with Articles 101 \&/or 102 TFEU require States to abstain from any action or enact any rule conflicting with the EU competition law provisions where a Member State requires or favours the adoption of agreements, decisions or concerted practices contrary to Article [101 TFEU] or reinforces their effects, or where that State divests its own rules of the character of legislation by delegating to private economic operators responsibility for taking decisions affecting the economic sphere. These provisions may limit the discretion of Member States to create statutory exemptions to the application of EU competition law rules by explicitly authorising, for instance, self-employed or associations of self-employed, to collective bargain with other undertakings.

A recent example of this rather restrictive approach is the CHEZ Elektro Bulgaria $v$. Yordan Kotsev case, concerning the setting of minimum fee amounts by a lawyers' professional organisation (the Supreme Council of the Legal Profession - SCLP in Bulgaria) ${ }^{60}$. The Court considered that Articles 4(3) TEU and Article 101 TFEU could not apply 'where the tariffs are fixed with due regard for the public-interest criteria defined by law and the public authorities do not delegate their rights and powers to private economic operators' and this 'even if representatives of the economic operators are not in the minority on the committee proposing those tariffs' ${ }^{\prime}$. The CJEU also noted that these experts should be 'independent of the economic operators' concerned and 'required, under the law, to set tariffs taking into account not only the interests of the undertakings or associations of undertakings in the sector which has appointed them but also the public interest and the interests of undertakings in other sectors or

\footnotetext{
${ }^{58}$ Commission Recommendation of 18 May 2005 on collective cross-border management of copyright and related rights for legitimate online music services, [2005] OJ L 276/54.

${ }^{59} \mathrm{See}$, for instance, representation agreements in which a collecting society appoints another society to administer rights on its behalf in a foreign territory, which were scrutinised in the CISAC decision because of territorial restrictions, to the extent that each society can issue licenses only for its own territory and users could only obtain a licence from their local collecting society, as the granted licence was limited to the domestic territory of the collecting society: see European Commission, Case COMP/C2/38.698 - CISAC (2008), available at http://ec.europa.eu/competition/antitrust/cases/dec_docs/38698/38698_4567_1.pdf . However, the EU General Court annulled the Commission's decision, finding that the EU Commission had not prove that the European societies engaged in a concerted practice aimed at restricting competition when they implemented identical territorial restrictions in their reciprocals, as it had no evidence for coordination between societies of the territorial scope of their mandates (i.e. no emails, letters or minutes of meetings). The Commission had also not convincingly rebut CISAC's argument that the existence of similar territorial restrictions (the 'parallel behavior') was not the result of coordination, but had other good reasons for it, such as the fact that protection and enforcement of rights require local presence and that it cannot be assumed that incentives to monitor and enforce rights continue to exist where there is competition between societies. See, Case T-442/08 CISAC v. European Commission, ECLI:EU:T:2013:188.

${ }^{60}$ Joined Cases C-427/16 and C-428/16, CHEZ Elektro Bulgaria v. Yordan Kotsev, ECLI:EU:C:2017:890.

${ }^{61}$ Ibid., para. 43.
} 
users of the services in question' ${ }^{32}$. The SCLP was composed exclusively of lawyers elected by their peers, the legislation did not provide any specific criterion ensuring that the minimum amounts of lawyers' remuneration, as this was determined by the SCLP, was fair and justified in accordance with the general interest, and it was subject to a limited constitutionality review. The CJEU concluded that the SCLP was not an arm of the State working in the public interest subject to actual review, but an association of undertakings. By making mandatory a decision of an association of undertakings which has the object or effect of restricting competition or restricting the freedom of action of the parties or of one of them could be subject to the joint application of Article 101(1) TFEU with Article 4(3) TEU. However, the fact that there is a prima facie restriction of competition does not mean that the practice will necessarily fall under the prohibition of Article 101(1) TFEU.

As mentioned above, the Albany exclusion provides immunity from competition law (Article 101 TFEU) to collective labour agreements concluded between associations of workers (labour unions) and employers, when two cumulative conditions are met:

(i) they are entered into in the framework of collective bargaining between employers and employees and

(ii) they contribute directly to improving the employment and working conditions of workers ${ }^{63}$.

The second criterion, relating to the purpose of the agreement, has been less problematic due to the fact that it has been interpreted broadly by the case law ${ }^{64}$. Limits of the second Albany condition were met in the FNCBV case, concerning an agreement between slaughterhouses and small farmers on prices for slaughtering animals and the suspension of imports after farmers' blockades of lorries in connection with the mad cow disease, the Court finding that the agreement did not relate to measures for improving conditions of work and employment, 'but to the suspension of beef imports and the fixing of minimum prices for certain categories of cows', whose object was to restrict competition ${ }^{65}$.

With regard to the first criterion, the situation has been more complex. It is clear that the case law does not recognise collective bargaining rights for self-employed, including microentrepreneurs. In Pavlov, the Albany exclusion was denied when self-employed are covered by collective agreement since 'the Treaty contains no provisions, $[\ldots]$ encouraging the members of the liberal professions to conclude collective agreements with a view to improving their terms of employment ${ }^{\prime 66}$. The Court refused to recognise an agreement setting up a pension fund for self-employed medical consultants as collective agreement, because the consultants were not employees. The agreement was nevertheless not considered as infringing Article 101

\footnotetext{
${ }^{62}$ Ibid., paras 44-45.

${ }^{63}$ Case C-67/96, Albany International BV v Stichting Bedrijfspensioenfonds Textielindustrie [1999] ECR I-5751, paras $62-63$.

${ }^{64}$ See the analysis in D. Schiek \& A. Gideon, Outsmarting the gig-economy through collective bargaining - EU competition law as a barrier to smart cities? (2018) 32 (2-3) International Review of Law, Computers And Technology 275,

${ }^{65}$ See Joined Cases T-217/03 and T-245/03, Fédération nationale de la coopération bétail et viande (FNCBV) and Fédération nationale des syndicats d'exploitants agricoles (FNSEA) v. Commission, ECLI:EU:T:2006:391, para. 100.

66 Case C-180/98, Pavel Pavlov and Others v Stichting Pensioenfonds Medische Specialisten, ECLI:EU:C:2000:428, para. 69.
} 
(1) TFEU because it did not appreciably prevent, restrict or distort competition (i.e. it was de minimis $)^{67}$. The General Court also found that the first Albany condition was not met in the $F N C B V$ case, although the French Labour Code considered the farmers as undertakings ${ }^{68}$, in particular among other things, because they did not work under the direction of the slaughterhouses ${ }^{69}$.

Another justification under Article 101(1) is possible if the restriction of competition is necessary for a legitimate regulatory purpose. In Wouters the CJEU examined the compatibility with Article 101 TFEU of a regulation adopted by the Dutch Bar Association prohibiting lawyers practising in the Netherlands from entering into multi-disciplinary partnerships with members of the professional category of accountants ${ }^{70}$. The CJEU found that the activities undertaken by self-employed lawyers could be considered to be an economic activity with the consequence that the regulation of the Netherlands Bar Association could be qualified as an association of undertakings. However, the CJEU noted that the Dutch Legislation entrusts the Bar of the Netherlands with responsibility for adopting regulations designed to ensure the proper practice of the profession, is that the essential rules adopted for that purpose are, in particular, the duty to act for clients in complete independence and in their sole interest, the duty, mentioned above, to avoid all risk of conflict of interest and the duty to observe strict professional secrecy. It took into account the public interest in assessing the existence of restrictions of competition under Article 101(1) TFEU, finding that the restrictions in question did not infringe Article [101(1) TFEU], since the effect restrictive of competition that is inherent in it, is necessary for the proper practice of the legal profession, as organised in the Member State concerned ${ }^{71}$. The Court took nevertheless note of the fact that the sound administration of justice is also to the benefit of the final consumer of judicial services ${ }^{72}$.

If this is not a de minimis restriction, Article 101(3) TFEU provides the last resort for a possible defence to a restriction of competition. However, that provision has rarely included public interest considerations of the kind taken into account in Wouters and Albany ${ }^{73}$. It very

\footnotetext{
${ }^{67}$ Ibid. paras $94 \& 97$.

${ }^{68}$ See Joined Cases T-217/03 and T-245/03, Fédération nationale de la coopération bétail et viande (FNCBV) and Fédération nationale des syndicats d'exploitants agricoles (FNSEA) v. Commission, ECLI:EU:T:2006:391, para. 58 .

${ }^{69}$ Ibid., para. 100.

${ }^{70}$ Case C-309/99 Wouters, Savelbergh and Price Waterhouse v Algemene Raad Van de Nederlandse Orde van Advocaten [2002] ECR I-1577.

${ }^{71}$ For another example, see Joined Cases C-184/13 to 187/13, C-194, 195 and C-208/13, API v. Ministero delle Infrastrutture e dei Transporti, ECLI:EU:C:2014:2147, paras 47-57 (exploring if the restriction of competition in question could be justified by the "legitimate objective" of the improvement of road safety).

72 Ibid., para. 97.

${ }^{73}$ In a number of cases dating before the adoption of Regulation 1/2003, the EU Courts recognized the discretion of the Commission in taking into account public interest objectives when implementing Article 101(3): Case C26/76, Metro v. Commission (Metro I) [1977] ECR 1875, para. 21: 'The powers conferred upon the Commission under [Article 101(3)] show that the requirements for the maintenance of workable competition may be reconciled with the safeguarding of objectives of different nature and to this end certain restrictions of competition are permissible, provided they are essential to the attainment of those objectives and they do not result in the elimination of competition for a substantial part of the common market'; Joined cases T-538/93, 542/93, 543/93 and 546/93, Métropole Télévision v. Commission [1996] ECR II-649, para. 118: 'in the context of an overall assessment, the Commission is entitled to base itself on considerations connected with the pursuit of the public interest in order to grant exemption under Article [101(3)]'. On the basis of this case law, the Commission has taken into account public interest considerations, such as employment policy and the protection of workers, cultural policy, environmental policy, the protection of public health, among others, when implementing Article
} 
much depends on the existence of a block exemption regulation, otherwise parties need to argue for an individual exemption (the burden of proof is on the defendant who needs to prove quite strict conditions). The restriction should be indispensable to achieve the efficiency gain or public interest, an 'equal share' of these efficiency gains should go back to the user (of the relevant market), the restriction should not lead to a substantial elimination of competition. Hence, in reality the possibility of justification in this context is particularly difficult.

This complex regime relies on a broad-brush categorisation of economic activities as 'labour', and thus subject to labour law, or entrepreneurship, subject to competition law, but the way the interaction between these two areas of law has been conceptualised leads to a conceptual and normative mismatch between the categories and purposes of the two disciplines, despite some effort made to avoid any normative conflicts that would arise out of the determination of the boundaries of each discipline. Hence, competition law made the necessary adjustments so as to enable labour to collectively bargain wages and working conditions, even if such collective bargaining may reduce the degree of competition in the labour market. The focus of competition law on product markets, rather than labour markets in this context may also have served well in order to avoid any conflict.

This approach of mutual ignorance, with some openness for the occasional readjustment, frustrates the goals of both areas of law. This frustration may well have been managed in the past, but the emergence of the New Economy Business Model has multiplied the areas of friction to the extent that the traditional categories of 'work' and 'undertaking' or 'self-employed' could not be stretched so as to ensure adequate protection for new forms of labour. To this one may add the multiplication of 'framing struggles' as each area of law made efforts to extend its own scope of application, sometimes without any in-depth consideration of the social effects of such strategy of legal imperialism.

It is also worth noting that in its most recent case law, the CJEU has taken a more circumspect view of the implications for the scope of EU competition law of the distinction between workers and self-employed persons, suggesting that the effective scope of EU competition law with regard to the self-regulation by the social partners of labour relations may be less based on categorical distinctions between workers and self-employed than on their conceptualization as a continuum going from situations of complete dependence (in which case the relation will be considered as akin to employment) to a situation of complete independence (in which case the entity in question will be considered as an independent undertaking). These points are further elaborated in the following Section, but cases such as FNV Kunsten ${ }^{74}$ raised the crucial question of the scope of competition law in view of the emergence of forms of work relationship, such as platform-based work, that put the traditional binary divide between employment and self-employment under strain. ${ }^{75}$ It also raised important questions as to the

101(3) TFEU. Since the adoption of Regulation 1/2003, and the end of the Commission's monopoly in enforcing Article 101(3) TFEU, the Commission seems to have moved towards a more restrictive position, as to the eligible 'improvements' to take into account.

${ }^{74}$ Case C-413/13, FNV Kunsten Informatie en Media, ECLI:EU:C:2014:2411.

${ }^{75}$ For a useful discussion, from a labour law but also an economic perspective, see MR Freedland and N Kountouris, The Legal Construction of Personal Work Relations (OUP, 2011); N Kountouris, 'The Concept of "Worker" in European Labour Law: Fragmentation, Autonomy and Scope' (2017) 47(2) Industrial LJ 192; A Stewart and J Stanford, 'Regulating Work in the Gig Economy: What are the Options?' (2017) 28(3) Economic and Labour Relations Rev 420 
optimal boundaries between competition law and labour law, and the possible extension of the workers' protection to the 'new jobs', a politically sensitive issue. ${ }^{76}$

\section{Breaking the dichotomy: building a continuum of legal protection for labour}

\section{A. A Changing Legal Landscape: The Treaty of Lisbon, the Charter, and Regulating for a Highly Competitive Social Market Economy}

The seeds of a more complementary vision of the relation between labour law and competition law dates may be found in some case law of the Court pre-dating the cataclysmic changes to the organisation of economic activity brought by the digital revolution. The Court's exclusion of collective agreements concluded by workers from EU Competition Law, clearly expressed in Albany, was premised on various treaty-based textual justifications ${ }^{77}$, and a recognition that the Treaties themselves 'promote close cooperation between Member States in the social field, particularly in matters relating to the right of association and collective bargaining between employers and workers' ${ }^{78}$. By contrast, in Pavlov, such an exclusion was denied when selfemployed are covered by collective agreement since 'the Treaty contains no provisions, [...] encouraging the members of the liberal professions to conclude collective agreements with a view to improving their terms of employment ${ }^{79}$ and this point was reiterated in FNV Kunsten ${ }^{80}$.

To the extent that this might have been an accurate description of the Treaty provisions at the time the Albany and Pavlov decisions were adopted, the coming into force of the Treaty of Lisbon in 2009 radically re-shaped the legal landscape and the Treaty sources on which the CJEU founds its case law. It is arguable that some of these changes also provide the context for the more nuanced and circumspect approach adopted in FNV Kunsten, both in the Court's judgment and, in particular, in AG Wahl's Opinion. Three such changes are worth mentioning in outline here, with the following section 5 drawing a number of normative implications from these changes.

Firstly, since 2009, the Charter of Fundamental Rights of the EU has come into force and the Charter recognises, in Article 28, that 'Workers and employers, or their respective organisations, have, in accordance with Union law and national laws and practices, the right to negotiate and conclude collective agreements at the appropriate levels'.

Secondly, the Charter itself has established a much firmer basis for interpreting its provisions in line with the relevant jurisprudence of the European Court of Human Rights (see Article 52(3) of the Charter) and has expressly 'reaffirmed' the European Social Charter.

\footnotetext{
${ }^{76}$ See, most recently, European Parliament, The Social Protection of Workers in the Platform Economy: Study for the EMPL Committee (November 2017), 11, available at www.europarl.europa.eu/RegData/etudes/STUD/2017/614184/IPOL_STU(2017)614184_EN.pdf (finding that 'the greater the level of financial dependence [of the labourer] on platform work, the lower the access that workers have to social protections').

${ }^{77}$ Case C-67/96, Albany International BV v Stichting Bedrijfspensioenfonds Textielindustrie [1999] ECR I-5751, paras 55-59.

78 Ibid., para 55.

79 Case C-180/98, Pavel Pavlov and Others v Stichting Pensioenfonds Medische Specialisten, ECLI:EU:C:2000:428, para 69.

${ }^{80}$ Case C-413/13, FNV Kunsten Informatie en Media, ECLI:EU:C:2014:2411, para. 29.
} 
Last, but not least, a new Article 9 TFEU was introduced, a provision with no direct predecessor in the earlier EC Treaties, this inclusion being particularly relevant in the context of the new model of 'social market economy' enshrined in Article 3(3) TEU. Judgments of the CJEU have already pointed out that both Article 9 TFEU and Article 3(3) TEU can play a fundamental role in expanding the Court's understanding of the social policy justification ${ }^{81}$, and it is fair to suggest that Article 9 TFEU, as all other horizontal integration clauses should provide interpretative guidance to the EU institutions when interpreting and applying the concepts of Article 101(1) and 101(3) TFEU.

We consider that these changes, jointly and severally, should first suggest a reformulation of the concepts of 'undertaking', 'agreement' and 'restriction of competition' in both Articles 101(1) and 101(3) TFEU, with a view of reconciling or reducing the gulf between the Albany and the Pavlov approaches. We also claim that they also make possible the abandonment of the dominant perception of these two fields as antagonistic in favour of a more complementary relation reconciling the different approaches and enabling for the first time a more systematic and congruent use of both legal tools in order to strengthen the protection of labour. Hence, in the next Section (B) we will explore the various strategies of reconciliation between labour law and competition law, while still adhering to the categorical thinking approach and viewing these two disciplines as two distinct legal fields, although not as isolated from each other as in the past. In the final Section (C) we move a step further and taking a problems approach dare to imagine a strategy that would aim to integrate the concepts and some of the tools of each discipline to each other, repurposing them for the occasion in order to address common concerns so that any action taken in one or the other context is mutually reinforced and the goals of both areas of law duly satisfied. Although this exercise requires some long-term investment and cannot be completed in this paper, for demonstration purposes we explore how competition law has already been re-designed and re-purposed in order to apply in labour markets, and ensure a higher degree of protection for labour.

\section{B. A Reconciliation between the Competition Law and Labour Law Approaches}

It is arguably possible to identify four main strategies to review and develop the interaction between competition law and labour law, taking into account their conceptualisation as separate legal fields with their own purposes and tools. The first consists in adopting a case-by-case analysis, examining the 'economic realities' of the relation between the hiring entity and the labourer, thus exploiting the potential offered by the FNV Kunsten case in order to design more realistically the boundaries between 'workers' and 'self-employed' (1). The second option is to exclude from the scope of competition law some categories of 'false self-employed' in order to preserve the effectiveness of provisions designed to prevent social dumping, which are negotiated and included in a collective agreement on behalf of and in the interests of workers, thus extending to this group labour law protection, with the aim to guarantee the internal

81 Case C-201/15, Anonymi Geniki Etairia Tsimenton Iraklis (AGET Iraklis) v Ypourgos Ergasias, Koinonikis Asfalisis kai Koinonikis Allilengyis, ECLI:EU:C:2016:972, paras 76 \& 78. 
consistency of $\mathrm{EU} \mathrm{law}^{82}$, in particular in the context of the application of the proportionality principle (2). A third option is to a categorical thinking, as opposed to case-by-case analysis, approach, by either expanding the existing category of 'workers', therefore excluding by the same the application of competition law in these situations (3). The common characteristic of the above options is that they operate with regard to the personal scope of competition law, attempting to establish clear boundaries as to whom is subject to it, and who is not. Another strategy would be to focus on the material scope of competition law, the concept of restriction of competition, which needs to be re-interpreted in conformity with the emphasis put recently by EU law on social market economy and collective bargaining, thus going beyond the strict confines of the legal consistency principle, in search of what we would characterize valuesconsistency (4).

1. Taking a functional approach: codifying the 'false self-employed' exception and/or employing the concept of 'economic dependence' for a case-by-case analysis

One may take an 'economic realities' perspective for both EU labour law and competition law building on the concept of economic (or technological) dependence. Looking to the category of 'work' (see Figure 1), we can identify two separate poles and then a number of situations that lie in the middle.

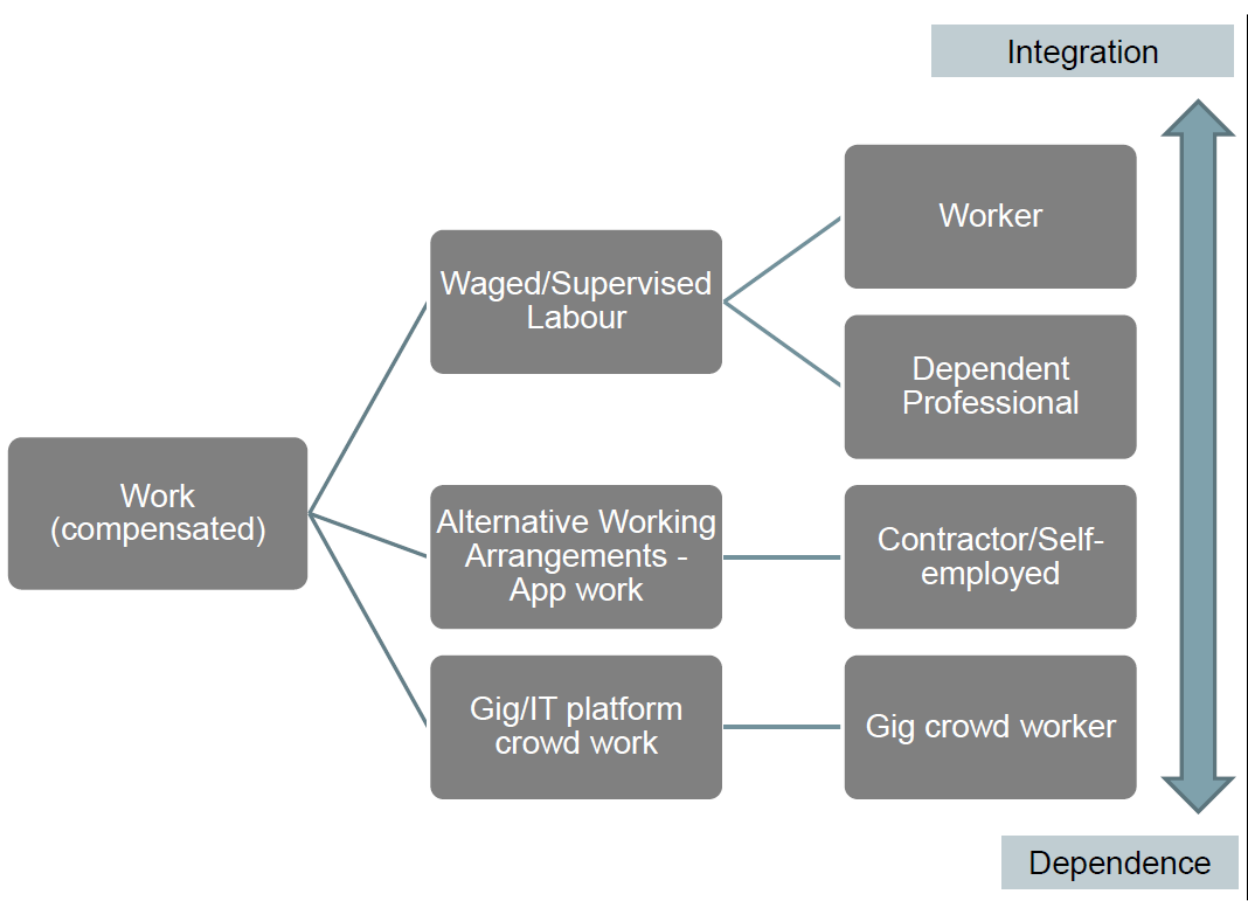

Figure 1: Dissecting the Category of 'Work' (compensated)

\footnotetext{
${ }^{82}$ On legal consistency in EU law, see C Franklin, The Burgeoning Principle of Consistency in EU Law (2011) Yearbook of European Law 11 ; E. Herlin-Karnell \& T. Konstadinides, The Rise and Expressions of Consistency in EU Law: Legal and Strategic Implications for European Integration, (2013) 5 Cambridge Yearbook of European Legal Studies 139; J. Langer \& W. Sauter, The Consistency Requirement in EU Law, 24 Colum. J. Eur. L. 39 (2017-2018) .
} 
We are inspired here by the classic distinction between 'hierarchy', conceived as a centralized pole of economic organization of production regulated by the employment contract and characterized by the hierarchical position of management ${ }^{83}$, and the 'market', considered as a decentralised institution that relies, in order to function, on price signals emitted by consumers/users of labour (as the archetypical market in our case will be labour markets), to which workers strive to respond. The key concept characterizing hierarchy is the full control of labour to the extent that this is integrated in an existing hierarchical structure. Of course, labour here is compensated though the payment of a wage by the employer. We do not distinguish for the purposes of this study between employers that are corporations and employers that are physical persons. Waged work is not the only category of supervised labour that may be integrated into the hierarchy. It is also possible to think of certain dependent professionals, for instance lawyers acting for a significant part of their time as in-house council for corporations, as also integrated into the boundaries of the firm.

While waged work constitutes one pole of 'work', the other one is constituted by labour expended in order to manage capital, own or capital borrowed in financial markets. The second pole of 'work' relies on the use of capital, the most extreme scenario being that labour becomes marginal or ancillary to the use of capital. This may include different forms of entrepreneurship (e.g. a restaurant owner that is at the same time the restaurant chef). In the middle, lie a certain number of alternative working arrangements that associate a worker to a specific task, but without integrating the worker in the hierarchy, as the worker remains in principle free to also provide work for other 'employers', although this formal freedom may be regulated, for instance, by non-competition clauses in the contractual relation. This category includes parttime workers, or gig and app work. This type of work has considerably increased in importance the last three decades.

The 'gig' economy is usually understood to include chiefly two forms of work ${ }^{84}$ : 'crowdwork' and 'work on-demand via apps'. The first term is usually referred to working activities that imply completing a series of tasks through online platforms. Typically, these platforms put in contact an indefinite number of organisations and individuals through the internet, potentially allowing connecting clients and workers on a global basis. IT platforms are used to source work "from an anonymous group of "bidders", who are referred to as the crowd, the provider and the worker frequently not having direct contact ${ }^{85}$. "Work on-demand via apps", instead, is a form of work in which the execution of traditional working activities such as transport, cleaning and running errands, but also forms of clerical work, is channelled through apps managed by firms that also intervene in setting minimum quality standards of service and in the selection and management of the workforce ${ }^{86}$. For instance, transport platform Uber uses technology to match customers with persons delivering work in the real

\footnotetext{
${ }^{83}$ Depending of course on the theory of the firm one may adopt.

${ }^{84}$ For a discussion, see V. De Stefano, The rise of the «just-in-time workforce»: On-demand work, crowdwork and labour protection in the «gig-economy», Conditions of Work and Employment Series No. 71, (ILO, Geneva, 2016), available at https://www.ilo.org/wcmsp5/groups/public/---ed_protect/---protrav/--travail/documents/publication/wcms_443267.pdf.

${ }^{85}$ See, D. Schieck \& A. Gideon, Outsmarting the gig-economy through collective bargaining - EU competition law as a barrier to smart cities?, (2018) 32(2-3) International Review of Law, Computers and Technology 275227. ${ }^{86} \mathrm{~V}$. De Stefano, The rise of the «just-in-time workforce»: On-demand work, crowdwork and labour protection in the «gig-economy», Conditions of Work and Employment Series No. 71, (ILO, Geneva, 2016), 1.
} 
world, such as offering a ride (cab services), delivering items (courier services), caring for children, the elderly or pets, gardening, or other craft services" ${ }^{\prime 7}$. The second relies on the IT platform (through an app) to source work "from an anonymous group of "bidders", who are referred to as the crowd, hence the name crowd sourcing', where frequently the provider and the worker will not have direct contact as the process is organised through the IT platform ${ }^{88}$. These archetypes 'represent points on continuum'89.

App-work consists in a digital platform matching a user/consumer with a pre-selected, by the platform, professional 'user' of the platform, who is already exercising this type of activity, and although in theory independent and self-employed, in reality relies on the platform technology, often through an app, to reach consumers/users at the other side of the platform. This pre-selection process and the fact that inclusion in the platform to be 'matched' with a user from the other side requires some form of governance of the platform with specific rules to which the app workers may abide to. Hence, this type of work may appear quite close to a traditional employment relationship, although there is no payment of wages in this occasion. Notwithstanding the non-integration of these workers in the hierarchy, for instance through the existence of a formal employment contract, the fact of the matter is that they also depend for their livelihood on their technological inclusion in the digital platform ecosystem. Often their relation with the platform takes the form of a commercial agency agreement, the genuine agency relations supposing that the agent acts as the long hand (longus manus) of the principal. However, courts have been quick to re-qualify these arrangements as functionally equivalent to employment, in view of certain characteristics accentuating this relation of dependence ${ }^{90}$.

Crowd-work may also lead to situations of dependence, if competition is limited because of the dominance of a platform on a specific (labour) market, or because of exclusionary strategies adopted by the platform. However, to the extent that the crowd worker is able to work for other platforms and collect an equal or significant part of his revenue from them, dependence becomes less of an issue. Dependence will of course increase the more the crowd-worker depends on work for a specific platform, in which case his situation may be considered as functional equivalent to a full-dependent worker.

The introduction of computing into work environments has profound implications on the nature of the working relation and requires a more functional perspective in envisioning the concept of 'work'. This should integrate the change from EOBM to NEBM, as well as the

\footnotetext{
${ }^{87}$ D. Schieck \& A. Gideon, Outsmarting the gig-economy through collective bargaining - EU competition law as a barrier to smart cities?, (2018) 32(2-3) International Review of Law, Computers and Technology 275.

${ }^{88}$ D. Schieck \& A. Gideon, Outsmarting the gig-economy through collective bargaining - EU competition law as a barrier to smart cities?, (2018) 32(2-3) International Review of Law, Computers and Technology 275227.

${ }^{89}$ Ibid.

${ }^{90}$ See, for instance, the approach of the UK Employment Tribunal (UKEAT)) regarding the employment status of Uber drivers: Uber B.V. and Others $v$ Mr Y Aslam and Others: UKEAT/0056/17/DA. The UKEAT rejected the label of agency used in the written contract between Uber and the drivers and qualified them as employees, although the drivers incurred commercial risks as they were responsible for all costs incidental to owning and running the vehicle, and were also able to work for or through other organisations, including direct competitors with Uber operating through digital platforms. The UKEAT arrived to this conclusion by adopting a purposive interpretation, taking into account the relative bargaining power of the parties, the integration of Uber drivers into Uber's business, in particular as, among other things, they were prevented from building up a business relationship with the end user of the service, they were in practice obliged to accept all trip requests if they wanted to keep their account status, and Uber held a significant market share in London, which left them no other equally effective competitive alternative.
} 
reality of the technological dependence of labourers to 'matching' platforms. Those involved in alternative work arrangements often find themselves in the role of entrepreneurs, drawing on their own personal assets, with all the attendant risks and rewards to this kind of economic activity ${ }^{91}$. Gig workers find themselves in the grip of the so-called platform economy, controlled by machines and managed by algorithms, into the working of which they do not have any access or insight, and with no recourse to legal labour protections. ${ }^{92}$ These changes also affects labour in different ways: low-skilled workers are facing stagnant or declining wages with an increasing prospect of intensified work through computer-coordinated mechanisms, while high-skilled professionals might be cognitively augmented in carrying out their work, and mid-level workers face the risk of job loss through technologies of automation. The net effect of these developments on waged labour is the 'hollowing out' of middle class, as observed in various societies ${ }^{93}$.

This functional approach has allegedly inspire the CJEU in FNV Kunsten ${ }^{94}$. In 2006, a collective labour agreement laying down minimum fees for 'employed' and 'self-employed' musicians substituting for members of an orchestra was concluded in the Netherlands. However, it was terminated shortly afterwards, as the Dutch Competition Authority was of the opinion that it was anti-competitive under Article 101 (1) TFEU. The national proceedings initiated by the trade union led to a request for a preliminary ruling to the Court of Justice of the European Union, which surprisingly asserted its jurisdiction despite the lack of any crossborder element. The Court put in place an exception to the application of competition law rules for 'false self-employed'. The CJEU expressly suggested that 'if the service providers, in the name and on behalf of whom the trade union negotiated, are in fact "false self-employed", that is to say, service providers in a situation comparable to that of employees', then Article 101(1) TFEU will not apply to these agreements ${ }^{95}$. The CJEU in FNV relied on the following two criteria for defining 'false self-employment':

- Dependence: 'the person does not determine independently his or her conduct on the

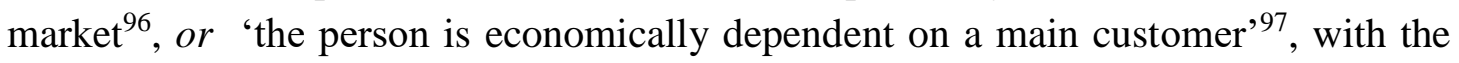
understanding that the person could be dependent on a main customer even if she derives an income from other customers as long as that additional income is marginal

\footnotetext{
91 J. Berg, Income security in the on-demand economy: Findings and policy lessons from a survey of crowdworkers. (International Labor Organization, 2016), available at https://www.ilo.org/wcmsp5/groups/public/---ed_protect/---protrav/---

travail/documents/publication/wcms_479693.pdf. U. Rani \& J. Berg, Digital labour platforms and the future of work: Towards decent work in the online world. ILO, Research Department. 2018; Neff, G. Venture Labor: Work and the Burden of Risk in Innovative Industries. The MIT Press. 2012

${ }^{92}$ Hara, K. et al. A Data-Driven Analysis of Workers' Earnings on Amazon Mechanical Turk. In Proceedings of the 2018 CHI Conference on Human Factors in Computing Systems (CHI'18) 2018.; V. DeStefano, 'Negotiating the Algorithm': Automation, Artificial Intelligence, and Labor Protection. ILO Employment Policy Department. Working Paper No. 246, 2018; S.F. Deakin \& C. Markou, The Law-Technology Cycle and the Future of Work (March 2018). University of Cambridge Faculty of Law Research Paper No. 32/2018.

${ }^{93}$ R. Wike, \& B. Stokes, B. (2018). In Advanced and Emerging Economies Alike, Worries About Job Automation. Pew Research Center. http://www.pewglobal.org/2018/09/13/in-advanced-and-emerging-economies-alikeworries-about-job-automation/

${ }^{94}$ Case C-413/13, FNV Kunsten Informatie en Media, ECLI:EU:C:2014:2411.

95 Ibid., paras 30-31.

${ }^{96}$ Ibid., para. 33.

${ }^{97}$ Opinion of AG Wahl in Case C-413/13, FNV Kunsten Informatie en Media, ECLI:EU:C:2014:2215, para 52
} 
or ancillary. The Court accepts that 'a service provider can lose his status of an independent trader, and hence of an undertaking, if he does not determine independently his own conduct on the market, but is entirely dependent on his principal, because he does not bear any of the financial or commercial risks arising out of the latter's activity and operates as an auxiliary within the principal's undertaking' ${ }^{98}$.

- Relationship for specified period of time: The service should be performed for and 'at direction' of principal, particularly in respect of time, place, and content of work.

We note that the reliance on the concept of economic dependence to exclude some selfemployed workers from the EU concept of undertaking is arguably compatible with the rationales of competition law and the approach followed in the context of genuine commercial agency agreements. This requires 'the Albany exclusion [to] be rephrased through a functional interpretation of the notion of undertaking in EU competition law. This would support an exclusion for all collective bargaining processes aimed at overcoming economic dependency of economically dependent service providers, irrespective from whether they are self-employed or not'.

The Court is open to this prospect on the basis that in Allonby, it had already held that the formal classification of a 'self-employed person' under national law 'does not exclude the possibility that a person must be classified as a worker ... if his independence is merely notional, thereby disguising an employment relationship ${ }^{\prime 99}$.

What are the implications of this case law for creatives? Writers, composers, and other providers of creative input are 'undertakings'. If they do not qualify as employees, their joint negotiation would be found to restrict Article 101(1) TFEU, by its object, if there is an agreement as to a minimum price across the industry, or by effect, in case the agreement in question may have price effects on the markets for the provision of various creative inputs. An industry-wide coordination would not satisfy the requirements of Art 101(3) TFEU to benefit from an exception to the prohibition rule. However, the definition of the category of 'false selfemployed' in $F N V$ would potentially exclude from the prohibition of Article 101(1) TFEU joint agreements between many workers in creative sector. To benefit from the exclusion, creatives should not have autonomy regarding the "time, place, and content" of the task in question and should not incur substantial financial or commercial risks. For instance, compensation partly based on revenue percentage would arguably create financial or commercial risk.

We note nevertheless that the reliance on the concept of economic dependence to exclude some self-employed workers from the EU concept of undertaking is arguably compatible with the idea in competition law that undertakings should behave as autonomous economic entities. Schiek and Gideon argue that in a number of sectors of the labour market 'multinational companies and other employers endeavour to shift the commercial risk onto the economically dependent self-employed persons', and they 'suggest that a truly economic approach to the notion of worker would recognise that this shifting of risk is an expression of economic dependency on the part of the worker or micro-entrepreneur'. This arguably requires

\footnotetext{
${ }^{98}$ Case C-413/13, FNV Kunsten Informatie en Media, ECLI:EU:C:2014:2411, para 33.

${ }^{99}$ Case C 256/01, Debra Allonby v Accrington \& Rossendale College, Education Lecturing Services, trading as Protocol Professional and Secretary of State for Education and Employment, ECLI:EU:C:2004:18, para 71 recalled in FNV Kunsten, above, at para. 35.
} 
'the Albany exclusion [to] be rephrased through a functional interpretation of the notion of undertaking in EU competition law. This would support an exclusion for all collective bargaining processes aimed at overcoming economic dependency of economically dependent service providers, irrespective from whether they are self-employed or not' ${ }^{100}$

The concept of economic dependence is well-understood in EU competition law and initially formed the main reason pure agency agreements were excluded from the scope of Article 101(1) TFEU. In Suiker Unie, the CJEU used two criteria to define the scope of the agency agreement regime. First, the agent should not bear any financial risk of the transaction. Second, the agent should not engage in the activities of both agent and one of independent trader in respect of the same market. ${ }^{101}$ The aim of the test is to verify the degree of autonomy of the agent with respect to the principal, which is determined according to the criterion of economic dependency. Being economically dependent or independent does not only result from the economic size of the agent or the fact that he also acts as an independent trader in respect of the same product market. As clarified by the Court in its successive jurisprudence, it may also be implied by other circumstances, such as the fact that the agent works for other principals. ${ }^{102}$

In applying Article 101(1) TFEU to agency agreements the Commission has previously noted that if the principal bears the commercial and financial risks related to the selling and purchasing of the contract goods and services 'all obligations imposed on the agent in relation to the contracts concluded and/or negotiated on behalf of the principal fall outside Article 101(1)'. ${ }^{103}$ In contrast, where the agent bears 'one or more of the relevant risks', 'the agreement between agent and principal does not constitute an agency agreement for the purpose of applying Article 101(1)' and in 'that situation the agent will be treated as an independent undertaking and the agreement between agent and principal will be subject to Article 101(1) as any other vertical agreement'. ${ }^{104}$ Although the CJEU expressed doubts on the criterion of economic dependence in Volkswagen ${ }^{105}$, by emphasizing the allocation of risks between the principal and the agent and the Commission followed by definitively abandoning the economic dependence criterion in the 2000 Vertical restraints guidelines for that of the allocation of risks ${ }^{106}$, we consider that there are close relations between the concept of economic dependence and the criterion of the allocation of risks between principal and agent that is now used in order to distinguish situations of 'genuine' commercial agency which benefit from some limited

\footnotetext{
${ }^{100}$ D. Schiek \& A. Gideon, Outsmarting the gig-economy through collective bargaining - EU competition law as a barrier? (2 ed.) 2018 CETLS Working Paper Series. DOI: https://www.qub.ac.uk/schools/SchoolofLaw/Research/European/FileStore/Filetoupload,815527,en.pdf , pp. 1314.

${ }^{101}$ Joined Cases 40 to 48, 50, 54 to 56, 111, 113 and 114/73, Coöperatieve Vereniging "Suiker Unie" UA and others $v$ Commission.

${ }^{102}$ See, Case C-311/85 ASBL Vereniging van Vlaamse Reisbureaus v ASBL Sociale Dienst van de Plaatselijke en Gewestelijke Overheidsdiensten [1987] ECR 3801, para 20.

${ }^{103}$ Commission notice - Guidelines on Vertical Restraints (Text with EEA relevance.) OJ C 291, 13.10.2000, p. $1-44$, para. 18.

${ }^{104}$ Ibid., para. 21.

${ }^{105}$ See, Case C-266/93 Bundeskartellamt $v$ Volkswagen AG and VAG Leasing GmBH [1995] ECR I-3477. The first step of the analysis would be to determine if the agreement could be characterized as a 'typical' commercial agency, by looking to the criterion of financial risks. If this was the case, then the second step would be to ascertain if the particular clause of the contract is necessary on account of its legal/economic nature.

${ }^{106}$ Vertical Restraints Guidelines [2000], paras 12-20
} 
immunity under Article 101(1) TFEU and that of non-genuine commercial agency agreements that fall under Article 101(1) TFEU.

We also consider that the case law on 'genuine' commercial agency agreements, if taken by analogy as the legal basis of an exception for self-employed when these are in situations of economic dependence and their agreement has the same aims as those of the agreements benefitting from the Albany exception, offers clear limiting principles, and in any case only offers partial immunity for certain types of agreements only. In the context of a 'genuine' commercial agency, the immunity does not expand clauses often included in commercial agency agreements, concerning the relationship between the agent and the principal, such as a provision preventing the principal from appointing other agents in respect of a given type of transaction, customer or territory (exclusive agency provisions) and/or a provision preventing the agent from acting as an agent or distributor of undertakings which compete with the principal (single branding provisions). With regard to these clauses, the agent is considered as a separate undertaking from the principal, that is the commercial agency immunity does not apply, and they may therefore be found to infringe Article 101(1) TFEU. ${ }^{107}$

We consider that by analogy the approach followed for 'genuine' commercial agency agreements will preserve the theoretical foundations and consistency of Article 101 TFEU, while enabling the Commission and other competition authorities to abide by the broader EU law principles regarding social protection and the horizontal integration clauses included in the Treaty, and more specifically Article 9 TFEU, which should at least serve as broader interpretative guidance for the provisions of the Treaty.

A broad functional approach that would apply case-by-case may nevertheless raise questions as to the limitations to the category of false self-employed, to the extent that situations of economic and technological dependence may occur in a variety of circumstances and could have a number of sources, depending on the idiosyncratic circumstances of each case, some of which it might be quite difficult for competition law enforcers to evaluate. Hence, a different approach would be not to proceed with a case-by-case multi-factor analysis but with a categorisation approach that would classify certain types of activity as more conducive to be considered as leading to a false self-employed status and specific criteria that if satisfied would establish a rebuttable presumption that the collective agreement was concluded by false selfemployed. The latter approach was followed by the Irish legislator in the recent amendment of the Competition Act 2002, which provides that Section 4 of the Competition Act (which prohibits anti-competitive agreements, decisions and concerted practices, similarly to Article 101 TFEU) shall not apply to collective bargaining in respect of a 'relevant category of selfemployed worker'.

More specifically, the Act provides a specific exemption for three named categories of self-employed workers: voiceover actors; session musicians; and freelance journalists. These workers have the right to bargain collectively with employers in relation to working conditions and terms of employment, including pay rates. The Irish Competition Act distinguishes between two relevant categories of self-employed workers that may be able to enter into collective bargaining agreements with employers:

(i) 'A 'false self-employed worker' is defined as an individual who

${ }^{107}$ Ibid., para. 19. 
- (a) performs for a person ('other person'), under a contract (whether express or implied and if express, whether orally or in writing), the same activity or service as an employee of the other person,

- (b) has a relationship of subordination in relation to the other person for the duration of the contractual relationship,

- (c) is required to follow the instructions of the other person regarding the time, place and content of his or her work,

- (d) does not share in the other person's commercial risk,

- (e) has no independence as regards the determination of the time schedule, place and manner of performing the tasks assigned to him or her, and

- (f) for the duration of the contractual relationship, forms an integral part of the other person's undertaking

(ii) A fully dependent self-employed worker is defined as an individual

- (a) who performs services for another person (whether or not the person for whom the service is being performed is also an employer of employees) under a contract (whether express or implied, and if express, whether orally or in writing), and

- (b) whose main income in respect of the performance of such services under contract is derived from not more than 2 persons

The Competition Act puts in place a procedure to apply for the benefit of the exception. Trade unions may apply to the Minister for Business, Enterprise and Innovation to permit groups of self-employed workers falling within these definitions to act collectively. As it is indicated in the amended Competition Act, the onus is on the Trade Union making the application to show that the self-employed workers they represent fall within the above definitions, and to also show that providing the exception (i) '(w)ill have no or minimal economic effect on the market in which the class of self-employed worker concerned operates, (ii) will not lead to or result in significant costs to the State, and (iii) will not otherwise contravene the requirements of this Act or any other enactment or rule of law (including the law in relation to the European Union) relating to the prohibition on the prevention, restriction or distortion of competition in trade in any goods or services'.

However, one should be mindful of the potentially limited effect in practice of such national exceptions to the application of competition law rules in the absence of an equivalent exception in EU competition law. Indeed, under Article 3(1) of Regulation 1/2003 Member States are obliged to apply Article 101 TFEU whenever they implement national competition provisions within the meaning of Article 101 (1) TFEU where those may affect trade on the internal market. It is also noted that the concept of 'effect on trade in the internal market' tends to be broadly construed by the Court.

2. A 'social dumping' rationale for excluding a broader range of 'false self-employed' from EU Competition Law

We believe that a third group of false self-employed workers should be excluded from Article 101(1) and that this exclusion can be premised on the anti 'social- dumping' rationale 
developed by AG Wahl in paragraphs 74-83 of his Opinion in FNV Kunsten ${ }^{108}$. In those paragraphs AG Wahl persuasively elaborated on whether the Dutch collective agreements met the Albany requirement that the provisions in the agreements are negotiated 'on behalf of and in the interests of workers'. AG Wahl concluded that 'that provisions designed to prevent social dumping, which are negotiated and included in a collective agreement on behalf of and in the interests of workers, are in principle to be regarded as improving directly their employment and working conditions, within the meaning of the Albany line of cases', but his analysis also has clear implication for the question of who should be covered by collective agreements (and which agreements could be exempted from EU competition law).

AG Wahl reached that conclusion on the basis of two main arguments pertaining to, in his words, the ' very raison d'être for collective bargaining', namely 'The elimination of wage competition between workers [which] implies that an employer can under no circumstances hire other workers for a salary below that set out in the collective agreement (para 76 of his Opinion); and 'that the possibility for employers to replace workers with other individuals in respect of whom they do not have to apply the working conditions laid down in the relevant collective agreement may significantly weaken the negotiating position of workers' (para 77).

AG Wahl correctly notes that '(o)n that basis, and from the perspective of a worker, there is really no difference if he is replaced by a less costly worker or by a less costly selfemployed person' 109 and that should that be possible, workers could not 'credibly ask for a salary increase if they knew that they could be easily and promptly replaced with self-employed persons who would probably do the same job for a lower remuneration' ${ }^{110}$. As such, the AG concluded that

'For all those reasons, I take the view that preventing social dumping is an objective that can be legitimately pursued by a collective agreement containing rules affecting selfemployed persons and that it may also constitute one of the core subjects of negotiation' ${ }^{111}$.

In the following paragraphs of his Opinion the AG goes on to illustrate how this rationale is supported by the case law ${ }^{112}$. He notes that for this justification to apply, there should be a concrete risk of a substitution by self-employed workers ${ }^{113}$. This is further elaborated as requiring the existence of 'a real and serious risk of social dumping, and, if so, whether the provisions in question are necessary to prevent such dumping. There must be an actual possibility that, without the provisions in question, a not insignificant number of workers might be replaced with self-employed persons at lower costs ${ }^{114}$, which requires the assessment that there be an 'actual possibility that, without the provisions in question, a not insignificant number of workers might be replaced with self-employed persons at lower costs') and 'whether

\footnotetext{
${ }^{108}$ Opinion of AG Wahl, in Case C-413/13, FNV Kunsten Informatie en Media, ECLI:EU:C:2014:2215.

109 Ibid., para 76.

${ }^{110}$ Ibid., para. 77.

${ }^{111}$ Ibid., para 79

${ }^{112}$ Ibid., paras 80-83.

113 Ibid., paras 99-94.

${ }^{114}$ Ibid., para. 89.
} 
they go beyond what would seem to be necessary to achieve the objective of preventing social dumping' ${ }^{115}$.

However, subject to these necessity and proportionality tests, there is an acceptance that self-employed person that genuinely compete with employees in a 'sector of the economy and the type of industry to which the collective agreement applies' could also be covered by collective bargaining (and benefit from an exception from competition law). This exclusion could be justified by taking into account the collective benefit of ensuring that the protective scope of labour legislation cannot be easily escaped. We note that, in the alternative, such social policy considerations should play a role in the context of Article 101(3) TFEU, as a form of collective benefits. ${ }^{116}$

So in addition to the 'false self-employed' and the 'economically dependent' categories illustrated above in the previous subsection, the Guidance should also grant a further exemption for 'genuinely self-employed persons in sectors and industries where the absence of a collective agreement covering their terms and conditions of employment may significantly weaken the negotiating position of workers in the industry by raisin a risk of social dumping or substitution'.

In 2016, ICTU lodged a collective complaint against Ireland with the European Committee on Social Rights (Council of Europe) regarding an alleged breach of Article 6.2 of the European Social Charter, due to the decision of the Competition Authority in the Actors' Equity Decision of $2004^{117}$. The complaint was heard by the European Committee of Social Rights (a quasijudicial body of legal experts appointed by the Council of Europe as the supervisory body for the Charter). Although the subsequent 2017 Act addressed some of ICTU's concerns, the trade union body pressed ahead with its complaint to the Committee on the grounds that (i) the 2017 Act only amended domestic Irish legislation and did not offer protection from EU law; and (ii) the scope of the Act was too limited. Following engagement with relevant parties, the complaint process concluded with a majority decision of the Committee being adopted in December 2018.

The Committee found 'that the ban on collective bargaining was not necessary in a democratic society and the situation that obtained before the entry into force of the 2017 Act was therefore in breach of Article $6 \S 2$ of the Charter' ${ }^{\prime 18}$. According to the Committee, 'collective mechanisms in the field of work are justified by the comparably weak position of an individual supplier of labour in establishing the terms and conditions of their contract' ${ }^{119}$. According to the Committee, '( $\mathrm{t}$ )his contrasts with competition law where the grouping of

\footnotetext{
115 Ibid., para 92.

${ }^{116} \mathrm{By}$ analogy to the way these were considered by the Commission in CECED (for the protection of the environment)

${ }^{117}$ European Committee of Social Rights, Complaint No. 123/2016, Irish Congress of Trade Unions (ICTU) v.
}

Ireland.

${ }^{118}$ European Committee of Social Rights, Decision on the Merits, Irish Congress of Trade Unions (ICTU) v. Ireland, Complaint No. 123/2016 (December 12 $2^{\text {th }}, 2018$ ), para. 101.

119 Ibid., para. 38 . 
interests of suppliers endanger fair prices for consumers ${ }^{120}$. The Committee made, in particular, reference to the trade union exception, noting that '(i)n establishing the type of collective bargaining that is protected by the Charter, it is not sufficient to rely on distinctions between worker and self-employed, the decisive criterion is rather whether there is an imbalance of power between the providers and engagers of labour' ${ }^{121}$. Indeed, '(w)here providers of labour have no substantial influence on the content of contractual conditions, they must be given the possibility of improving the power imbalance through collective bargaining ${ }^{122}$. According to the Committee, 'the ban was excessive and therefore not necessary in a democratic society in that the categories of persons included in the notion of "undertaking" were overinclusive' ${ }^{123}$. As the Committee explained, '( $t$ )he self-employed workers concerned here are obviously not in a position to influence their conditions of pay once they have been denied the right to bargain collectively' ${ }^{124}$. Importantly, the Committee considered that the Irish competition law prior to the 2017 amendment amounted to a 'ban on collective bargaining' and that as such it was 'excessive and therefore not necessary in a democratic society' ${ }^{125}$. In conclusion, according to this case law when a Member State sustains an over-inclusive scope of competition law, it can breach its obligations under Article 6(2) of the Charter. As the 2017 Act removed the restriction to Article $6 \$ 2$ of the Charter the Committee did not have an issue with the amendment.

\section{A new concept of 'worker'}

A further option might be that of either expanding the concept of 'worker' for all areas of EU law, or decoupling the 'worker' definition in EU competition law from the 'worker' definition in EU labour law. While the 'worker' concept in labour law is, and could remain predominantly attached to the notion of subordination and control, the notion of 'worker' in EU competition law could develop in ways that take into account more specifically the regulatory rationales of competition law (in particular the presence of concentration and market power in particular sectors) and maintain a meaningful distinction between 'worker' and 'undertaking' for the discipline.

The current definition of 'worker' adopted in EU Competition law cases replicates the definition developed in the areas of Free movement of Workers, which is also increasingly deployed to cast or recast the scope of application of EU Employment Law instruments. In essence it requires work to be performed under the direction of another (subordination criterion) ${ }^{126}$, to be remunerated work (pay criterion), and to amount to a genuine economic activity (genuine economic activity criterion). The CJEU has interpreted very liberally the

\footnotetext{
120 Ibid.

121 Ibid.

122 Ibid.

${ }^{123}$ Ibid., para 94.

124 Ibid., para 95.

125 Ibid., para. 98.

${ }^{126}$ See, Case C-413/13, FNV Kunsten Informatie en Media, ECLI:EU:C:2014:2411, para. 37.
} 
second (in cases like Matzak $^{127}$ ) and third criteria (in cases like Fenoll ${ }^{128}$ ), but the first criterion remains a cardinal defining feature of the 'worker' definition.

But some judgments of the Court, and some AG Opinion, have begun to develop a more nuanced understanding of the concept of the subordination criterion, as also being evidenced from indirect and attenuated forms of control or cooperation. In Danosa the Court included within the scope of Directive 92/85 a pregnant member of the board of directors of a capital company. ${ }^{129}$ In this case the Court expressly noted that even though, because of her managerial role, Ms Danosa 'enjoyed a margin of discretion in the performance of her duties', ${ }^{130}$ she had to be treated as a 'worker' covered by the directive because, inter alia, 'she had to report on her management to the supervisory board and to cooperate with that board' ${ }^{131}$ The Court adopted a generous and nuanced notion of subordination that does not require an employer to be constantly watching over the shoulders of a worker, and can effectively amount to a power of 'control', 'direction or supervision', ${ }^{133}$ or 'to cooperate, ${ }^{134}$ especially when such workers are 'an integral part of ${ }^{\prime} 135$ the company the provide services to.

There is a growing recognition that, especially in the case of platform work, subordination cannot be expected to manifest itself in the traditional sense of a power to direct or to issue formal orders to workers. In APET v Uber, AG Szpunar carefully recognised that

'51. [...]Uber exerts control over all the relevant aspects of an urban transport service: over the price, obviously, but also over the minimum safety conditions by means of prior requirements concerning drivers and vehicles, over the accessibility of the transport supply by encouraging drivers to work when and where demand is high, over the conduct of drivers by means of the ratings system and, lastly, over possible exclusion from the platform. [...] Uber therefore controls the economically significant aspects of the transport service offered through its platform.

52. While this control is not exercised in the context of a traditional employeremployee relationship, one should not be fooled by appearances. Indirect control such as that exercised by Uber, based on financial incentives and decentralised passengerled ratings, with a scale effect, [...] makes it possible to manage in a way that is just as - if not more - effective than management based on formal orders given by an employer to his employees and direct control over the carrying out of such orders. ${ }^{136}$,

\footnotetext{
${ }^{127}$ C-518/15, Ville de Nivelles v Rudy Matzak, ECLI:EU:C:2018:82.

${ }^{128}$ C-316/13, Gérard Fenoll v Centre d'aide par le travail "La Jouvene" and Association de parents et d'amis de personnes handicapées mentales (APEI) d'Avignon, ECLI:EU:C:2015:200.

${ }^{129}$ Case C-232/09, Dita Danosa v LKB Līzings SIA, ECLI:EU:C:2010:674, paras 38-42.

${ }^{130}$ Ibid., para 49.

131 Ibid.

132 Ibid., para 51.

133 Ibid., para 56.

${ }^{134}$ Ibid., para 49.

${ }^{135}$ Ibid., para 56.

136 Opinion of AG Szpunar in Case C-434/15, Asociación Profesional Elite Taxi v Uber Systems Spain, S, ECLI:EU:C:2017:364.
} 
Some of these considerations were replicated in the judgment by the CJEU (esp. at para 39). The Court recognised in particular that 'Uber exercises decisive influence over the conditions under which that service is provided by those drivers'.

The CJEU has repeatedly acknowledged that 'the classification of a 'self-employed person' under national law does not prevent that person being classified as an employee within the meaning of EU law if his independence is merely notional, thereby disguising an employment relationship' (see para 35 of the FNV Kunsten judgment, but also para 71 of the Allonby judgment). Hence, the CJEU and the other EU institutions are entitled to provide their own definitions of 'worker' for the purposes of applying EU law, including of course EU competition law. Advocate General Wahl also accepted this view because 'in today's economy, the distinction between the traditional categories of worker and self-employed person is at times somewhat blurred" 137 and 'the self-employed are a notoriously vast and heterogeneous group' ${ }^{138}$. This approach will enable courts to re-characterize self-employed to workers, taking into account that over-inclusiveness of the category of workers may produce less negative welfare effects than enabling the digital platforms to misclassify workers to independent contractors and may have positive distributional implications for workers. As Hagiu and Wright explain, employees enjoy greater bargaining power (e.g., through unions) than independent contractors, so their surplus exceeds what would have been their outside option in case they were considered employees. Hence, 'there can be higher gains to workers when true independent contractors are misclassified as employees, and also greater losses to workers when true employees are misclassified as independent' ${ }^{139}$.

We submit that a Guidance Document could offer a specific clarification of the term 'worker' for the purposes of the application of EU competition law as amounting to

'A worker is a person that for a certain period of time is engaged by another to perform mainly personal work or services in return for which he receives remuneration.

Such work or services may be performed under the direct control, indirect control, or decisive influence of the employer or involve a duty to cooperate with employer's direct or indirect instructions'

We prefer this option to the proposals advanced by some authors to introduce a hybrid category of workers to whom to extend some labour protection, ${ }^{140}$ including immunity of the relevant collective bargaining from competition law. A number of authors, including Countouris and De Stefano and several contributions published in this special issue, ${ }^{141}$ already

\footnotetext{
${ }^{137}$ Opinion of AG N. Wahl in Case C-413/13, FNV Kunsten Informatie en Media, ECLI:EU:C:2014:2215, para 51.

${ }^{138}$ Ibid., para. 55.

139 A. Hagiu \& J. Wright, The status of workers and platforms in the sharing economy, (2019) 28 Journal of Economics Management \& Strategy 97, 106.

140 A. Hagiu \& J. Wright, The status of workers and platforms in the sharing economy, (2019) 28 Journal of Economics Management \& Strategy 97, 106; Seth D. Harris and Alan B. Krueger, 'A Proposal for Modernizing Labor Laws for Twenty-First-Century Work: The "Independent Worker" (2015) The Hamilton Project, Discussion Paper 2015-10 <

http://www.hamiltonproject.org/assets/files/modernizing_labor_laws_for_twenty_first_century_work_krueger_ harris.pdf>

${ }^{141}$ See Nicola Countouris and Valerio De Stefano, New Trade Union Strategies for New Forms of Employment (ETUC, 2019).; Valerio De Stefano, The rise of the «just-in-time workforce»: On-demand work, crowdwork and labour protection in the «gig-economy», Conditions of Work and Employment Series No. 71, (ILO, Geneva,
} 
engaged multiple times with the shortcomings of these proposals. In particular, legal systems where something along the lines of hybrid categories were introduced experienced increased levels of litigation and uncertainty, caused by the fact that parties had to litigate over three rather than two employment statutes. At the same time, many workers who would have been classified as fully-fledged employees, with access to employment protection in its entirety, had a hybrid category not been introduced, were denied basic employment rights without they being substantially different from traditional employees. No positive effects in terms of innovation, productivity or consumer welfare have been proved to be associated with the past introduction of hybrid categories.

4. A purposive re-interpretation of collective bargaining as having a marginal and secondary effect in light of recent Treaty changes

The Court's exclusion of collective agreements concluded by workers from EU Competition Law in Albany was premised on various treaty-based textual justifications ${ }^{142}$, and a recognition that the Treaties themselves "promote close cooperation between Member States in the social field, particularly in matters relating to the right of association and collective bargaining between employers and workers'. By contrast, in Pavlov, such an exclusion was denied when the self-employed are covered by collective agreement since 'the Treaty contains no provisions, [...] encouraging the members of the liberal professions to conclude collective agreements with a view to improving their terms of employment' (para 69 of Pavlov) and this point was reiterated in paragraph 29 of FNV Kunsten.

However, as noted above in section 4 above, since 2009, the Charter of Fundamental Rights of the EU has come into force recognising, in Article 28, that 'Workers and employers, or their respective organisations, have, in accordance with Union law and national laws and practices, the right to negotiate and conclude collective agreements at the appropriate levels'. The Charter, in Article 52(3) also provides that 'In so far as this Charter contains rights which correspond to rights guaranteed by the Convention for the Protection of Human Rights and Fundamental Freedoms, the meaning and scope of those rights shall be the same as those laid down by the said Convention'.

Its Preamble also 'reaffirms [...] the rights as they result, in particular, from [...] the Social Charters adopted by the Union and by the Council of Europe' noting that ' [i]n this context the Charter will be interpreted by the courts of the Union and the Member States with due regard to the explanations prepared under the authority of the Praesidium of the Convention which drafted the Charter and updated under the responsibility of the Praesidium of the European Convention'. The explanations prepared by the Praesidium confirm that 'Article 28 - Right of collective bargaining and action [...] is based on Article 6 of the European Social Charter and on the Community Charter of the Fundamental Social Rights of Workers'.

2016), 1; Miriam A. Cherry and Antonio Aloisi, 'Dependent Contractors' in the Gig Economy: A Comparative Approach 66 (2017) American Univ. L. Rev. 635. See also, in this special issue, the article of Hitesh Dhorajiwala and Mark Freedland, the article of Elena Gramano and Giovanni Gaudio and the article of Elisabeth Brameshuber. ${ }^{142}$ See, Case C-67/96, Albany International BV v Stichting Bedrijfspensioenfonds Textielindustrie [1999] ECR I5751, paras 55-59. 
As noted above, in the recent decision on Irish Congress of Trade Unions (ICTU) $v$. Ireland (Complaint No. 123/2016) the Committee of Social Rights affirmed that it 'has constantly held that in principle the provisions of Part II of the Charter apply to the selfemployed except where the context requires that they be limited to employed persons. No such context obtains in a generalised way for Article 6\$2.' (para 35 of the decision) and that 'an outright ban on collective bargaining of all self-employed workers would be excessive as it would run counter to the object and purpose of this provision' (para 40).

It is arguable that this decision fundamentally recasts the scope of Article 28 of the CFREU, and that this provision should also be understood as not automatically excluding or banning self-employed workers from the right to bargain collectively.

The Committee of Social Rights also noted that 'the right to bargain collectively is not an absolute right and that it may be restricted by law where this pursues a legitimate aim and is necessary in a democratic society' and that '[i] this respect it cannot be automatically presumed that restrictions following from competition law [...] do not pursue a legitimate aim and/or are not necessary in a democratic society, for example to protect the rights and freedoms of others' (paragraph 36). Therefore EU competition law may also be considered as justifiably restricting the scope of Article 28 CFREU.

However, in our view, these developments call into question the assumption on which Pavlov and FNV Kunsten excluded automatically collective agreements covering selfemployed workers from the Albany exception. Given the expanded personal scope of Article 28 CFREU, it is arguably no longer the case that 'the Treaty contains no provisions, [...] encouraging the members of the liberal professions to conclude collective agreements with a view to improving their terms of employment'.

These developments require EU institutions to consider the possibility that collective agreements applying to self-employed workers providing personal work and services may be considered as falling outside the scope of EU competition law, if they meet the same conditions that collective agreements covering workers are expected to fulfil, and if the self-employed persons in question are not genuine undertakings operating a business in their own account. This would be consistent with the growing recognition that the right to bargain collectively is a fundamental right protected both at a Treaty level, at an international level, and in the constitutional traditions common to the Member States of the European Union.

We note that in cases such as Wouters, the Court noted that while some agreements between undertakings may restrict competition, "not every agreement between undertakings or every decision of an association of undertakings which restricts the freedom of action of the parties or of one of them necessarily falls within the prohibition laid down in Article 85(1) of the Treaty [now Article 101(1) TFEU]. For the purposes of application of that provision to a particular case, account must first of all be taken of the overall context in which the decision of the association of undertakings was taken or produces its effects. More particularly, account must be taken of its objectives, which are here connected with the need to make rules relating to organisation, qualifications, professional ethics, supervision and liability, in order to ensure that the ultimate consumers of legal services and the sound administration of justice are provided with the necessary guarantees in relation to integrity and experience [...]. It has then 
to be considered whether the consequential effects restrictive of competition are inherent in the pursuit of those objectives' ${ }^{143}$.

It could be claimed that collective agreements setting minimum terms and conditions of employment applicable to self-employed workers, could now (i.e. in light of the entry into force of Article $28 \mathrm{CFREU}$ and of the recent ICTU $v$ Ireland decision), could be seen as pursuing social objectives that are compatible with and protected by the Treaties, and - in the absence of other regulatory options - they could also be seen as a necessary and efficient means to achieve such objectives. While they may entail some restriction of competition, such restriction may only be a 'consequential effect' inherent in the pursuit of a protected objective, i.e. the protection of the terms and conditions of some self-employed workers, that by reason of being able to generate income predominantly or exclusively by the sale of mainly personal work or services to one main/a limited number of customer/s are unable to act as free agents in the market. A similar point is also supported by academic work carried out by Schiek and Gideon. ${ }^{144}$

\section{Designing Competition Law for Labour Market Power Regulation}

The separate and antagonistic spheres approach followed so far with regard to the interaction between competition law and labour law, led to the conceptualisation of these two areas of law in isolation to each other, competition law applying merely to 'undertakings', while labour law protecting 'workers', with the interplay between the two being conceived negatively as merely ensuring that the aims followed by one will not be jeopardised by the application of the other. This approach may explain why issues of the respective scope of competition law and labour law became the central theme of this interaction, with an attempt to ensure that the application of competition law will not limit the ability of trade unions to collective bargain with employers and protect the rights of workers. The exclusion of employees from the scope of competition law in Becu, the exception introduced by Albany, but also other possibilities of justification of such collective bargaining under EU competition law rules, such as the ancillary regulatory restrictions approach of Wouters, the 'false-self employed' exception recently introduced by $F N V$, and Article 101(3) TFEU all consider the interplay between competition law and labour law from the rather defensive perspective of enabling collective bargaining and do little in putting forward a competition law agenda that would actively engage with restrictions of competition in labour markets with the aim to protect labour. It is submitted that this approach and the primary role recognised to collective bargaining follows from the emphasis put on exploitation in Marxist and neo-Marxist approaches, as well as the emphasis on the establishment of countervailing powers to tame the rising power of corporations, which is a feature of institutional economics and Keynesian economics ${ }^{145}$.

${ }^{143}$ Case C-309/99, Case C-309/99, JCJ Wouters, JW Savelbergh and Price Waterhouse Belastingadviseurs BV $v$ Algemene Raad van de Nederlandse Orde van Advocaten, intervener: Raad van de Balies van de Europese Gemeenschap [2002] ECR I-1577, para. 97.

${ }^{144}$ D. Schiek \& A. Gideon, Outsmarting the gig-economy through collective bargaining - EU competition law as a barrier? (2 ed.) (2018) CETLS Working Paper Series. DOI:

https://www.qub.ac.uk/schools/SchoolofLaw/Research/European/FileStore/Filetoupload,815527,en.pdf , 14-15. ${ }^{145}$ On countervailing powers and their role in ensuring equilibrium in capitalist systems, see J.K. Galbraith, American Capitalism- the Concept of Countervailing Power (Houghton Mifflin, 1952). 
It is nevertheless possible to adopt a more pro-active agenda in envisioning the relation of competition law and labour, by putting forward the enforcement of competition law, rather than, or in conjunction with, the establishment of exceptions to the enforcement of competition law in order to preserve the possibilities of collective bargaining, in order to deal with the market failures affecting the optimal performance of labour markets and leading to the exploitation of workers, in particular tackle labour market power.

Labour market power has been defined as 'the ability of employers to set wages below workers' marginal revenue product', which denotes the existence of labour exploitation, a concept that has nothing to do with the concept of exploitation employed by the labour theory of value inspiring Marxist approaches, as it only focuses on the exploitation of labour by virtue of the imperfection of the (labour) market ${ }^{146}$. A labour market has been defined as 'a group of jobs, between which workers can switch with relative ease (for example, computer programmers, lawyers, or unskilled workers) located within a geographic area usually defined by the commuting distance of workers'. ${ }^{147}$ The concept assumes that there exists a 'spot market' for labour hours, firms employing a number of workers for a specific amount of hours. Under the profit maximization principle, a firm would employ a number of workers whose net marginal product equals the marginal cost of labour, in terms of wages paid. One may conceive the employment relation as a joint venture between owners of capital and workers to the extent that firms combine labor $(\mathrm{L})$ and capital $(\mathrm{K})$ to produce output $(\mathrm{Q})$. The marginal product of a typical worker varies over time. Joan Robinson employed for her definition of exploitation the 'marginal physical productivity of labour', which she defined as 'the increment of output caused by employing an additional unit of labour with a fixed expenditure on other factors' ${ }^{148}$. The employment relationship results in a gap between the workers' marginal product at the firm and their alternative wage offers (in real terms). According to Robinson, exploitation may occur due to the workers' weaker bargaining power than the employers', the 'fundamental cause' of exploitation being 'the lack of perfect elasticity in the supply of labour or in the demand for commodities' ${ }^{149}$. Exploitation may be monopolistic, if this results from imperfections in the commodities market (even if the labour market is competitive), or monopsonistic, if this is due to imperfect elasticity of the supply of labour (even if the product market is perfectly competitive $)^{150}$. In situations of monopsonistic exploitation, the wage would equal the supply price of the employee, which would be inferior, because of imperfect competition, to the value of the marginal physical product of labour. Although a minimum wage would remove this kind of exploitation as well as contribute other tangible economic benefits, ${ }^{151}$ it would also have as an effect to increase production costs, and may lead to a number of negative effects. First, it may increase prices for consumers, if these high costs

\footnotetext{
146 See, J. Robinson, The Economics of Imperfect Competition (MacMillan, 1933), 283, noting that 'a group of workers are being exploited when their wage is less than the marginal physical product that they are producing, valued at the price at which it is being sold'.

${ }^{147}$ S. Naidu, E.A. Posner \& G. Weyl, Antitrust Remedies for Labor Market Power, (2019) 132 Harvard Law Review 537, 539.

${ }^{148}$ J. Robinson, The Economics of Imperfect Competition (MacMillan, 1933), 236.

${ }^{149}$ Ibid., 281.

150 Ibid.

${ }^{151}$ S. Deakin and F. Wilkinson, 'The Law and Economics of the Minimum Wage' (1992), Journal of Law and Society, 379.
} 
would be passed on to the consumers in the commodity market, hence workers may lose as consumers more than what can be offset by their gain as wage earners. Second, it may lead to labour factor substitution with a decrease in the level of employment.

As it is succinctly summarised by Marinescu and Hovenkamp the 'key message from economic theory is that as one moves away from the competitive equilibrium towards a situation of monopsony in the (labour) market, wages and production both generally tend to decrease ${ }^{152}$.

Labour market power may have different sources. First, with the rise of economic concentration, it is highly likely that a few firms would operate in a given labour market, that is in a given labour market only one or few employers will be able to hire from the available pool of workers ${ }^{153}$, may hold monopsony power. This provides them the power to reduce wages below what the workers would have been paid had the labour market be competitive. The monopsonist may thus enjoy a higher monopsony surplus, reducing by the same the surplus left to labour. This is not just a theoretical possibility as there has been recent empirical research documenting the rise of labour market concentration in the $\mathrm{US}^{154}$. The result of labour monopsony or more generally labour market power is that the workers are paid below their marginal revenue product. As noted by the latest OECD Outlook 2019 publication, '[w]hile most of this evidence typically refers to employees, there are some studies quantifying the extent to which independent contractors, including platform workers, may be exposed to monopsony power'. ${ }^{155}$

Economic concentration in industries or product markets does not always lead to monopsony or oligopsony and labour market power. There are a number of market characteristics to take into account requiring some elaborate analysis of the interplay of supply (of labour) and demand in the specific market. One may use the hypothetical monopolist test (or Small Significant and Non transitory Increase in Price Test or SSNIP) which is adopted by

${ }^{152}$ I. Marinescu \& H.J. Hovenkamp, Anticompetitive Mergers in Labor Markets, (2018). Faculty Scholarship at Penn Law. 1965. https://scholarship.law.upenn.edu/faculty scholarship/1965 11 .

${ }^{153}$ E. A. Posner, G. Weyl \& S. Naidu, Antitrust Remedies for Labor Market Power, (2018) 132 Harvard Law Review 536, 539.

${ }^{154}$ See, J. Azar, I. Marinescu \& M. Steinbaum, Labour Market Concentration, IZA Institute of Labour Economics (December 2017), available at https://www.econstor.eu/bitstream/10419/177058/1/dp11254.pdf (documenting labour market concentration for over 8,000 geographic-occupational labour markets in the US and finding that the average market is highly concentrated, this concentration being associated with a $17 \%$ decline in posted wages, therefore suggesting that concentration increases labour market power). These results were supplemented by a subsequent study exploring estimates of labour market concentration to cover almost all online job postings in the United States for the year 2016 compiling an HHI (Herfindahl-Hirschman index) for each commuting zone by 6digit SOC occupation: J. Azar, I. Marinescu, M. Steinbaum, B. Taska, Concentration in US Labor Markets: Evidence from Online Vacancy Data (August 10, 2018). Available at SSRN: https://ssrn.com/abstract=3133344 (finding that the average labour market has an HHI of 4,378, or the equivalent of 2.3 recruiting employers and that $60 \%$ of labor markets are highly concentrated (above 2,500 $\mathrm{HHI}$ ). The HHI is a concept developed by economists and used by many competition authorities as a screen to assess likely market power of two or more merging firms. It is derived by adding the square of the market share of every firm in the market. This emphasises the importance for competition by the larger firms.

155 OECD, Employment Outlook 2019, (Paris, 2019), p.154, referring in particular to the studies by Dube et al.

'Monopsony in Online Labor Markets', American Economic Review: Insights (forthcoming) providing evidence that workers on Amazon Mechanical Turk can have a residual labour supply elasticity as low as 0.1 , while Chevalier et al. 'The Value of Flexible Work: Evidence from Uber Drivers', Journal of Political Economy (forthcoming) find values comprised between 1 and 2 for Uber drivers. 
the European Commission's Notice on Market Definition for product markets ${ }^{156}$. This typically aims to measure cross-price elasticity between two products through a speculative experiment postulating a hypothetical small but lasting change in relative prices [5-10\%] and evaluating the likely reactions of customers to that increase. The important parameter that such a test enables us to observe is the price elasticity of demand facing the hypothetical monopolist: if the demand is elastic, then it would not make sense for this monopolist to implement profitably the SSNIP and therefore the relevant market needs to be broadened; if the demand elasticity is low, then it would be profitable for the monopolist to implement the SSNIP, and therefore the relevant market should be narrowed down. In our context, the test should be adjusted for gauging monopsony labour power. Hence, it will explore the hypothetical monopsonist's ability to impose a 'Small Significant Non-transitory Reduction in Wages' (SSNRW test) looking to the elasticity of labour supply in the hypothetical market ${ }^{157}$. The geographical dimension of these labour markets may be determined according to some evidence on work commuting. For instance, Marinescu and Hovenkamp suggest the use as a starting point in the analysis for geographic markets of 'Observed Commuting Zones (CZs)', which are 'geographic area definitions comprising clusters of counties that were developed by the United States Department of Agriculture (USDA) based on based on data from the 2000 Census on commuting patterns across counties to capture local economies and local labour markets ${ }^{158}$. With regard to product markets, they suggest the use as a starting point of the analysis of six digits Standard Occupational Classification (SOC) codes and a job title (e.g. senior as opposed to junior accountant), which may define markets by occupational category ${ }^{159}$. The purpose of this test and of the market definition exercise in general is to determine, indirectly, the existence of labour market power. The competition authority may compile market shares in these labour markets and determine if a specific undertaking or undertakings hold a dominant position or more generally market power.

However, in the context of labour markets, concentration is not always a necessary condition for the finding of labour market power. This is because there may be different sources of labour market power, such as product differentiation and search frictions ${ }^{160}$. These may be particularly strong in some cases, for instance because of the absence of other economic activities in the specific region and the dominant presence of one employer, so that even an individual firm may be considered as an antitrust labour market ${ }^{161}$. The difficulties of people to move in different places to search for work because of personal attachments (family, friends

\footnotetext{
${ }^{156}$ Commission Notice on the definition of relevant market for the purposes of Community competition law, [1997] OJ C 372/5.

${ }^{157}$ For a detailed analysis, see M. Steinbaum, Antitrust, the Gig Economy, and Labor Market Power (June 12, 2019). Law and Contemporary Problems, 2019, available at SSRN: https://ssrn.com/abstract=3347949 ; E. A. Posner, G. Weyl \& S. Naidu, Antitrust Remedies for Labor Market Power, (2018) 132 Harvard Law Review 536, 574-575.

${ }^{158}$ I. Marinescu \& H.J. Hovenkamp, Anticompetitive Mergers in Labor Markets, (2018). Faculty Scholarship at Penn Law. 1965. https://scholarship.law.upenn.edu/faculty_scholarship/1965 18.

159 Ibid., 18.

${ }^{160}$ E. A. Posner, G. Weyl \& S. Naidu, Antitrust Remedies for Labor Market Power, (2018) 132 Harvard Law Review 536, 541.

${ }^{161}$ M. Steinbaum, Evidence and Analysis of Monopsony Power, Including but not limited to, in labour markets, Roosevelt Institute (August 2018), available at file://ad.ucl.ac.uk/homea/uctlioa/Documents/ftc-2018-0054-d0006-151013.pdf.
} 
or local community), language and cultural factors, economic factors (such as a mortgaged home) also indicate that it is not possible to purely and simply transpose to labour markets the assumptions driving the assessment of market power in product markets (and in particular the baseline assumption of perfect competition). Hence, it is important to stay open to the idea that there may exist labour market power even in non-concentrated labour markets. The difficulty in this case would be for competition law to develop adequate metrics so as not for these instances of labour market power to escape the scrutiny of competition authorities.

A possible option is to rely on a multi-factor analysis that would take into account different sources of evidence of labour market power/monopsony. First, employers with labour market power are able to impose to workers adverse conditions on employment. These can take the form of non-compete clauses which go beyond what is necessary to protect the transfer of know-how to the worker, other disadvantageous terms (such as longer working hours, mandatory arbitration and class action waivers or broad non-disclosure agreements) without compensation, deferred compensation agreements or any other working conditions that depart from the norm in the specific industry or more broadly. Although the analysis may in some instances require to first look to 'abnormal' conduct or performance before addressing the issue of the market structure, thus inversing the traditional approach in determining the existence of market power, it is not unprecedented ${ }^{162}$. Second, Steinbaum puts forward as evidence of labour market power 'the prevalence of earnings inequality between similar workers who work at different firms in the same (labour) market' to the extent that in 'a competitive labor market, the existence of outside job offers at the market wage makes the (labour) supply curve infinitely elastic to individual firms' and '(a)ny worker paid less than they are worth would leave for a better offer' ${ }^{163}$. Another source of direct evidence of labour market power is when 'quits do not correspond very much to wage changes', this evidence being easier to comply in the context of digital labour platforms (such as Amazon Turk) where tasks and workers tend to be homogeneous and therefore easily comparable ${ }^{164}$.

Hence, it has been suggested that policy-makers develop a broader list of criteria to take into account in defining the existence of labour market power. These recommendations include the following:

- a (rebuttable) presumption that 'a market share of over $50 \%$ of employment (or alternatively, of posted job vacancies) in a well-defined antitrust (labour) market' may constitute evidence of market power';

- '(t)he ability to lower wages below what would be charged in a competitive market';

\footnotetext{
162 It is indeed possible that economic methods may be used to assess market power directly by focusing on changes in market power, examining for instance a historical counterfactual without the challenged practices in order to decide if a conduct has increased market power (a retrospective analysis in the situation of an agreement or abusive conduct), or providing an analysis of the change in incentives (a prospective analysis for instance regarding mergers) in order to examine of the conduct is likely to increase market power. Profitability analysis or the fact that there has been permanent price discrimination or price stability can also be used as factors, among others, enabling competition authorities to infer the existence of market power. For a discussion, see JB Baker and T Bresnahan, 'Economic Evidence in Antitrust: Defining Markets and Measuring Market Power', in Paolo Buccirossi (ed.) Handbook of Antitrust Economics (MIT Press, 2008), 1.

${ }^{163}$ M. Steinbaum, Evidence and Analysis of Monopsony Power, Including but not limited to, in labour markets, Roosevelt Institute (August 2018), available at file://ad.ucl.ac.uk/homea/uctlioa/Documents/ftc-2018-0054-d0006-151013.pdf. 2.

164 Ibid.
} 
- '(t)hee ability to wage-discriminate, that is, to pay similar workers working in the same market significantly different wages';

- '(t)he ability to impose disadvantageous nonwage contractual terms on workers without compensation' 165 .

One may also argue for the analysis of the superior bargaining power of some employers, in view for instance of significant investments made by the workers for their education and training for the specific job, which make it quite difficult for them to switch if these costs are non-recoverable in their new job or occupation. In some economic sectors (for instance the fashion industry) working for a specific undertaking may also provide an important quality certification to the worker in terms of status and prestige in the profession, which it would be difficult to get elsewhere, thus further limiting the available options of employment to workers and their incentive to switch and by the same providing labour market power to the specific employer. Although situations of economic and technological dependence may not be provide any interesting insights as to the existence of labour market power for workers in employment contracts and thus integrated to the undertaking, they may be significant factors to take into account when considering conduct involving gig workers or self-employed that may be qualified as separate undertakings under EU competition law.

Developing new concepts in order to gauge labour market power is not the only reform to undertake. It is also crucial to reflect on specific antitrust theories of harm and metrics that would fit the goal of protecting labour from the negative effects of monopsony. Such theories of harm would apply across the various areas of competition law, in the assessment of anticompetitive collusion, abuse of dominance or merger control. Reducing wages obviously constitutes a prevalent theory of harm in this context. This may result from various types of conduct: horizontal cartel-like conduct, such as non-poaching agreements ${ }^{166}$, or supplier wage suppression the monosponist orchestrating cartels between supplies to reduce the wage of their

\footnotetext{
${ }^{165}$ J. Azar, I. Marinescu \& M. Steinbaum, Antitrust and Labor Market Power, Econfip Research Brief (May 2019), available at https://econfip.org/wp-content/uploads/2019/05/Antitrust-and-Labor-Market-Power.pdf . See also I. Marinescu \& H. Hovenkamp, "Anticompetitive Mergers in Labor Markets," Faculty Scholarship at Penn Law, February 20, 2018, https:// scholarship.law.upenn.edu/faculty_scholarship/1965;

${ }^{166}$ See, the US Department of Justice (DOJ) and Federal Trade Commission (FTC), Antitrust Guidance for Human Resource Professionals (October 2016), available at https://www.justice.gov/atr/file/903511/download 3 (finding that agreements among employers not to recruit certain employees or not to compete on terms of compensation are illegal and also raising concerns for agreements to share information with competitors about terms and conditions of employment (although they also acknowledge that not all information exchanges are illegal) but also the active investigation by the DOJ, using its criminal enforcement authority, of non-poaching agreements in various sectors: see, U.S. v. Knorr-Bremse AG and Westinghouse Air Brake Technologies Corporation, https://www.justice.gov/atr/case/us-v-knorr-bremse-and-westinghouse-air-brake-technologies ; In Re: Railway Industry Employee No-poach Antitrust Litigation, No. 2:2018mc00798 - Document 192 (W.D. Pa. 2019); Seaman, et al. v. Duke University and Duke University Health System, https://www.justice.gov/atr/case/danielleseaman-v-duke-university-et-al and various class actions brought by private plaintiffs, in particular In re: HighTech Employee Antitrust Litigation (N.D. Cal. No. 11-CV-2509-LHK) regarding agreements between the executives of Adobe Systems, Apple, Google, Intel, Intuit, Lucasfilm, and Pixar to eliminate competition among them for skilled labour which was settled in September 2015 for $\$ 415$ million (see, https://www.reuters.com/article/apple-google-ruling/u-s-judge-approves-415-mln-settlement-in-tech-workerlawsuit-idUSL1N11908520150903 ). In Europe, the Italian competition authority (AGCM) fined eight modelling agencies a total of $€ 4.5$ million for wage fixing agreements: see https://www.agcm.it/media/comunicatistampa/2016/11/alias-8448 . The UK CMA imposed fines totalling $£ 1,533,500$ on 5 model agencies for colluding instead of competing on prices for modelling services: https://www.gov.uk/government/news/model-agenciesfined-15-million-for-price-collusion.
} 
workers and then pass on some of the savings to the monopsonist upstream ${ }^{167}$. Some of these theories of harm are more speculative ${ }^{168}$. For instance, predatory hiring as an abuse of a dominant position where the incumbent monopsonist raises wages above the workers' marginal revenue product in order to exclude a new competitor from the market, as this would not be able to make profits and following the exit of the competitor the incumbent would be able to reduce wages below the workers' marginal revenue product ${ }^{169}$.

Merger control will certainly become an important area of competition law enforcement regarding the effect of mergers (horizontal or vertical) on labour markets. One may expect the application of unilateral non-coordinated theories of harm in the context of horizontal mergers (mergers between competitors). Simply put, a horizontal merger reduces competitive rivalry to the extent that the target company exert a competitive constraint. Furthermore, other competitors benefit from the fact that the merged entity behaves less competitively than the two merging firm would have done absent the merger in question. The decision of the firms to increase prices following the merger, is motivated by the fact that part of the loss in sales is being captured by (diverted to) the other merging firm. Therefore, the closer are the substitute products of the merging firms, the stronger is the incentive of the merged entity to increase prices. Similar analysis may be performed as to the incentive of the merging firms to reduce wages, if the two merging firms were close competitors in labour markets An interesting concept suggested in the context of merger control to estimate this unilateral effect is that of 'Downward Wage Pressure' (DWP) which aims to measure the effects of a merger on the wages of the workers in the labour markets affected. This concept/metric is analogous to the 'Upward Pricing Pressure' (UPP) that is used in merger control to determine the extent to which a merger and the consequent removal of a competitive constraint will alter the margins of the merging firms, the elimination of competition between the merging firms generating upward pricing pressure as the merging firm will be able to internalise the profits on sales diverted to what would be now a part of the same undertaking. UPP also takes into account the mergerspecific efficiency improvements which may tend to offset the upward pricing pressure. DWP may be inspired by similar principles ${ }^{170}$. However, labour theories of harm may not only be take the form of lower wages, but may also relate to the quality of the employment relation, the ability of workers to benefit a fair share from increases in their productivity, because of innovation, thus affecting their incentives, and other anticompetitive strategies that may affect the share of the gains accruing to workers (as opposed to management and investors).

There is still little experience among competition authorities with assessing the effects of a restriction of competition on labour market. There is however some interesting experience in South Africa about the effects of mergers on employment, as part of the public interest test adopted under South African competition law ${ }^{171}$. There is case law under South African

167 E. A. Posner, G. Weyl \& S. Naidu, Antitrust Remedies for Labor Market Power, (2018) 132 Harvard Law Review 536, 597.

168 Ibid., 598.

169 Ibid., 598-599.

${ }^{170}$ For a discussion, see E. A. Posner, G. Weyl \& S. Naidu, Antitrust Remedies for Labor Market Power, (2018) 132 Harvard Law Review 536, 578-583 (also suggesting merger simulation as a way forward to estimate anticompetitive effects in labour markets).

${ }^{171}$ For an excellent discussion, see A. Raslan, Mixed Policy Objectives in Merger Control: What Can Developing Countries Learn from South Africa? (2016) 39(4) World Competition 625. 
competition law on merger specific retrenchments ${ }^{172}$, which also proceeds to an analysis of alternative employment opportunities for the workers that were fired as a result of the merger. Including employment considerations in the analysis, in addition to concerns over wage reductions and restrictions on the conditions of employment, will require a broader standard that would be closer to a public interest one. In any case the emphasis that this rapidly developing competition law literature puts on the anticompetitive effects on labour markets already breaks with the narrow vision of consumer welfare standard and the emphasis on product markets that has prevailed so far in competition law. This raises interesting questions as to a more optimal and complementary relation between competition law and labour law.

In conclusion, new competition law concepts and metrics and the way protection of labour considerations can be integrated in the current competition law framework constitutes a fertile area for future research.

\section{Conclusions}

In drawing our conclusions we would like to point out that the maintaining the status quo of the tense relationship between labour law and competition law outlined in the opening sections of this paper, is not a sustainable option. The legal uncertainty produced by a variety of both domestic competition authorities and EU court rulings favour the denial of rights to a number of weekly positioned labour market participants and, in the context of a fissured, fragmented, and digitally mediated labour market, promotes a undesirable race to the bottom (or 'social dumping' to borrow the words used by AG Wahl in his Opinion in FNV Kunsten) between differently classified workers performing equivalent or identical personal work services for a variety of employing entities. The latter clearly benefit from the status quo, chiefly by accumulating the profits that they fail to redistribute to their increasingly diverse workforce and establishing themselves as dominant players in a variety of markets. But they do so by eating into labour's share of wealth generation, producing a range of negative externalities arising from growing income inequality, and actually by distorting the very markets that competition law is, or should be, tasked with regulating and protecting.

The European Union is based on respect for democracy and social rights. According to Article 3 (3) of the Treaty on the European Union, the Union shall establish an internal market with a highly competitive social market economy, aiming at full employment and social progress and will work to 'promote social justice and protection'. We believe that this dual commitment - to a competitive economy which promotes social justice - should be honoured and reflected in the application of EU competition law.

In this paper we have articulated the view that sustaining a prohibition on collective bargaining for the totality of the self-employed without possibilities for exemption for particular groups of weekly positioned self-employed workers, places Member States in the difficult position of choosing whether to breach their obligations under EU law or under the European Social Charter and a number of other European and international labour and human rights treaties. In this respect, it is important to note that Article 6 of the Treaty on the European

172 To be distinguished from operational employment loss, which is dealt under labour law, although the distinction is not always easy to make. 
Union establishes that the European Union shall accede to the European Convention of Human Rights, and that all EU Member States are also members of the International Labour Organisation, and thus bound, inter alia, by ILO Conventions 87 and 98.

Although it is possible for National Competition Authorities to set their own priorities in initiating competition law investigations, and that one may expect that a common approach developed under the ECN that would provide some flexibility to the adoption of collective bargaining by the self-employed, in particular when they are in the presence of significant power imbalances in bargaining between individual self-employed workers and employers, there is still the risk that collective agreements may be found to infringe Article 101 TFEU by national courts, thus leading to the possibility of damages awards for the benefit of the 'victims' of such practices. It is therefore essential that the Commission takes the initiative in this area and provides the required legal certainty and the uniform interpretation of EU competition law provisions.

On the basis of the analysis carried out in the previous sections we suggested that it would be desirable and possible for the Commission to adopt a Guidance Document to assist public authorities, trade unions, employers and employers' organisations with the interpretation and application of competition law to collective agreements whose terms are applicable to selfemployed workers. Drawing from the CJEU jurisprudence and the opinions of a number of Advocate Generals, we have suggested that, in our view, this Guidance Document should outline the following:

'Collective agreements covering workers, including self-employed workers providing personal work and services, should be exempt from the application of EU competition law if they pursue the objective or protecting minimum terms and conditions of employment and the effects restrictive of competition are merely consequential and inherent to the pursuit of those objectives.

In particular, collective agreements that contain minimum terms and conditions of employment or work that apply to workers, including self-employed workers providing mainly personal work and services, should be exempt from EU Competition Law rules if such agreements cover:

- Workers understood as persons that for a certain period of time are engaged by another to perform mainly personal work or services in return for which they receives remuneration. Such work or services may be performed under the direct control, indirect control, or decisive influence of the employer or involve a duty to cooperate with employer's direct or indirect instructions.

- False self-employed persons defined as persons that

o provide personal work or services in a situation comparable to that of employees, or

- do not determine independently their conduct on the market, or

o are economically dependent on a main customer, with the understanding that the person could be dependent on a main customer even if she derives an income from other customers as long as that additional income is marginal or ancillary 
$\bigcirc$ are not operating a genuine undertaking and operating a business on their own account.

- Self-employed persons providing personal work and services in sectors and industries where the absence of a collective agreement covering their terms and conditions of employment may significantly weaken the negotiating position of workers in the industry by raising a risk of social dumping or substitution'

We consider that both competition law and labour law should get inspiration from the 'economic realities' approach and embrace economic and technological dependency as a criterion for distinguishing between 'workers' and 'self-employed'. Both should also envisage some of the strategies discussed in III.B., with the aim to develop a consistent approach across both areas of law. This objective may be further facilitated by two strategies: first, competition law enforcement should increasingly focus on labour markets, rather than just on product markets in order to tackle labour market power; second, there should be sufficient flexibility in the context of Article 101(1) TFEU, for enabling dependent self-employed to collectively bargain with the digital platforms, thus improving their working conditions and their revenue share. For instance, the immunity regime for commercial agency agreements may offer the opportunity to the Commission and NCAs to take a more functional approach of the category of 'worker', thus implementing the broader EU law principles regarding social protection and the horizontal integration clauses included in the Treaty, and more specifically Article 9 TFEU, which should at least serve as broader interpretative guidance. As a last resort, the adoption of Article 10 Regulation 1/2003 decisions, providing a detailed analysis under Article 101(3) TFEU, or eventually a block exemption regulation for 'platform labour', under Article 103 TFEU, that would exempt certain forms of collective bargaining, may also improve legal certainty.

As the various articles in the present special issue of the European Labour Law Journal point out, EU Member States still value the importance of collective bargaining as an essential tool for labour market regulation. The comparative perspectives contained therein have by and large corroborated the narrative and normative arguments underlying the ETUC report New Trade Union Strategies for New Forms of Employment and the finding that it may be both possible and desirable for labour law to embrace a broader concept of worker, shaped by reference to the idea of personal work relation. We see the suggestions contained in the present article, and the central recommendation of realigning the goals of competition law and those of labour law in the context of national collective bargaining processes, as an essential part of a reform agenda that, in our view, should unite both the European labour movement, EU institutions, and that essential and vibrant part of European capitalism that values the long term viability of Europe's 'highly competitive social market economy'. 